\title{
Particle Radiation-Induced Nontargeted Effects in Bone-Marrow-Derived Endothelial Progenitor Cells
}

\author{
Sharath P. Sasi, ${ }^{1}$ Daniel Park, ${ }^{1}$ Sujatha Muralidharan, ${ }^{2}$ Justin Wage, ${ }^{1}$ Albert Kiladjian, ${ }^{1}$ \\ Jillian Onufrak, ${ }^{1}$ Heiko Enderling, ${ }^{3}$ Xinhua Yan, ${ }^{1,4}$ and David A. Goukassian ${ }^{1,2,4}$ \\ ${ }^{1}$ Cardiovascular Research Center, GeneSys Research Institute, Boston, MA 02135, USA \\ ${ }^{2}$ Whitaker Cardiovascular Institute, Boston University School of Medicine, Boston, MA 02118, USA \\ ${ }^{3}$ Department of Integrated Mathematical Oncology, H. Lee Moffitt Cancer Center and Research Institute, Tampa, FL 33612, USA \\ ${ }^{4}$ Tufts University School of Medicine, Boston, MA 02118, USA
}

Correspondence should be addressed to David A. Goukassian; david.goukassian@tufts.edu

Received 29 December 2014; Revised 23 February 2015; Accepted 24 February 2015

Academic Editor: Daniele Avitabile

Copyright (C) 2015 Sharath P. Sasi et al. This is an open access article distributed under the Creative Commons Attribution License, which permits unrestricted use, distribution, and reproduction in any medium, provided the original work is properly cited.

\begin{abstract}
Bone-marrow- (BM-) derived endothelial progenitor cells (EPCs) are critical for endothelial cell maintenance and repair. During future space exploration missions astronauts will be exposed to space irradiation (IR) composed of a spectrum of low-fluence protons $\left({ }^{1} \mathrm{H}\right)$ and high charge and energy (HZE) nuclei (e.g., iron- ${ }^{56} \mathrm{Fe}$ ) for extended time. How the space-type IR affects BM-EPCs is limited. In media transfer experiments in vitro we studied nontargeted effects induced by ${ }^{1} \mathrm{H}$ - and ${ }^{56} \mathrm{Fe}$-IR conditioned medium (CM), which showed significant increase in the number of p-H2AX foci in nonirradiated EPCs between 2 and $24 \mathrm{~h}$. A 2-15-fold increase in the levels of various cytokines and chemokines was observed in both types of IR-CM at $24 \mathrm{~h}$. Ex vivo analysis of BMEPCs from single, low-dose, full-body ${ }^{1} \mathrm{H}$ - and ${ }^{56} \mathrm{Fe}$-IR mice demonstrated a cyclical (early 5-24 h and delayed 28 days) increase in apoptosis. This early increase in BM-EPC apoptosis may be the effect of direct IR exposure, whereas late increase in apoptosis could be a result of nontargeted effects (NTE) in the cells that were not traversed by IR directly. Identifying the role of specific cytokines responsible for IR-induced NTE and inhibiting such NTE may prevent long-term and cyclical loss of stem and progenitors cells in the BM milieu.
\end{abstract}

\section{Introduction}

Long lasting, up to 2 years, ionizing radiation- (IR-) induced chromosomal instability had been reported in vivo in the bone marrow (BM) after full body exposure to X-rays or neutrons $[1,2]$. In addition, it has been shown that after space flights the number of myeloid and lymphoid BM-derived stem and progenitor cells were reduced to just one-half of their normal population [3]. In spite of these reports there is significant gap in assessing the effects of low-dose full body IR on the survival and function of BM stem and progenitor cells, including BM-derived endothelial progenitor cells (BMEPCs). These earlier findings suggest that the number of EPCs may be similarly reduced in the normal BM-EPC population during and after space flights. Additionally, IR-induced DNA damage in BM may affect significantly the number and function of BM-EPCs. Subsequently reduced number and function in EPCs and other BM stem and progenitor cell populations may affect adversely cardiac homeostasis during normal aging, as well as the repair and regeneration processes after cardiac injury.

Radiobiological bystander responses (RBR) are the phenomena in which nonirradiated (Non-IR) cells exhibit responses similar to effects manifested by IR cells as a result of signals received from either nearby or distant IR cells. Radiobiological bystander responses of IR on a variety of primary and tumor cells have been well-documented in vitro [4-10]. RBR-mediated effects can be attributed to events initiated near the Non-IR cell surface that in turn activates and integrates various intracellular signaling pathways 
that are regulated by RBR [11]. It is important to clarify here that the ability to induce RBR [7] and the ability to receive the IR-induced RBR signaling is cell-, cytokine-, and chemokine-specific [4]. Further, specific ligand-receptor interactions on Non-IR cells may play key role in the propagation of $\mathrm{RBR}[4,12,13]$ in the remote site from the original site of IR exposure cells and tissues, including cells in the BM milieu.

Our focus on BM-EPCs stems from considerable body of evidence regarding the role of EPCs in repair and regeneration and postnatal angiogenesis (neovascularization) processes after ischemic injury. In various animal models [1417] and human clinical trials [18-21] our laboratory and others have shown that transplantation of BM cells and BMEPCs leads to migration and homing of these cells to the areas of damage, where EPCs contribute to the processes of neovascularization leading to the development of collateral vessels, which then contribute to the recovery of blood flow in the damaged tissue such as the heart [22-26], hind limb [27-29], bone [30-33], liver [34-36], and brain and spinal cord [37-41]. Consequently a decrease in the total number of BM-EPCs or their dysfunction could contribute to the pathogenesis of ischemic and/or peripheral vascular diseases. This could also have negative impact on the recovery after tissue injury, as well as negatively affect the maintenance of normal vascular homeostasis in the organs and tissue in general. We therefore tested whether BM-derived EPCs may exhibit radiobiological bystander responses in vitro and determined the effect of low-dose full-body particle IR on the survival of BM-derived EPCs in vivo.

\section{Material and Methods}

2.1. Animal Models. To determine low-dose full-body proton $\left({ }^{1} \mathrm{H}\right)$-IR and iron $\left({ }^{56} \mathrm{Fe}\right)$-IR induced effects on survival of BM-derived EPCs, adult 8-10 months old male C57Bl/6NTac mice were shipped directly from Taconic (Hudson, NY) to Brookhaven National Laboratory (BNL) to be irradiated at NASA Space Radiation Laboratory (NSRL). Mice were kept in the temperature- and light-controlled environment and handled in accordance with IACUC guidelines and protocols approved by GeneSys Research Institute (GRI) and BNL.

2.2. Radiation and Dosimetry. Full-body low-dose space-type IR experiments for low linear energy transfer (LET) ${ }^{1} \mathrm{H}$ IR and high-LET ${ }^{56} \mathrm{Fe}$-IR exposures were performed at the BNL in the NSRL according to standardized procedures. For both ${ }^{1} \mathrm{H}$ and ${ }^{56} \mathrm{Fe}$ full-body IR mice were placed in individual polypropylene boxes with $4 \mathrm{~mm}$ holes drilled to produce a stress-free environment. LET levels for both particle radiations were held constant and the average doserate of $16.7 \pm 5 \mathrm{cGy} / \mathrm{min}$ for ${ }^{1} \mathrm{H}$-IR and $5 \pm 0.5 \mathrm{cGy} / \mathrm{min}$ for ${ }^{56} \mathrm{Fe}$-IR to deliver a cumulative dose of $90 \mathrm{cGy}$ for ${ }^{1} \mathrm{H}$ and $15 \mathrm{cGy}$ for ${ }^{56} \mathrm{Fe}$, respectively. Constant energy of $1,000 \mathrm{MeV} /$ nucleon (n) was used to deliver both, ${ }^{1} \mathrm{H}$ - and ${ }^{56} \mathrm{Fe}$-IRs. Mice exposed to low-dose particle IR were driven back to GeneSys Research Institute (GRI) animal facility from
BNL for housing and experimental analysis. Control NonIR mice for each ion species was sham-IR; that is, mice were placed in the same individual polypropylene boxes, taken to the irradiation "cave," and placed on beam line platform for the same duration of the time for each ion, but not irradiated.

2.3. Medium Transfer Experiments in BM-EPCs after ${ }^{1} H$ $I R$ and ${ }^{56} \mathrm{Fe}-I R$. We isolated BM-EPCs from mononuclear cell (MNC) fraction of total bone marrow isolated from tubular bones by flushing tibiae and femurs of ${ }^{1} \mathrm{H}-\mathrm{IR},{ }^{56} \mathrm{Fe}-$ IR, and Non-IR mice using density gradient centrifugation. MNCs were then cultured on $22 \times 22 \mathrm{~mm}$ square glass coverslips (Fisher Scientific, Pittsburg, PA) precoated with $0.2 \%$ gelatin (Sigma, St Louis, MO) in 6-well dishes (Corning Inc., Corning, NY). BM-EPCs were expanded $e x$ vivo in selective EBM-2 growth medium supplemented with bullet kit growth factors (Lonza, Hopkinton, MA) until they attained $\sim 70-80 \%$ confluence as described previously $[15,28,42]$. These BM-EPCs cultured in EBM-2 growth medium have been previously characterized for the following markers: $\beta$-gal (biological EC marker-cells were grown from Tie2/LacZ mice) and c-kit (stem/progenitor cell marker) wherein we demonstrated that $95-100 \%$ of cells by days 4 and 6 were double positive for both markers [28]. We also used two additional markers, Isolectin-B4 and Flk-1, which also showed similar results by day 6 in culture [28]. In our recent publication we further determined the purity of our BMEPC cultures for other lineage specific hematopoietic cells, wherein we have performed immunofluorescent staining of these cells with antibodies for Grl/Ly-6G (neutrophils), F4/80 (macrophages and blood monocytes), CD45R/B220 (B lymphocytes), CD3 (T lymphocytes), and TER-119 (erythrocytes and erythroid precursors) [13]. These BM-EPCs have been shown to be negative for $\mathrm{B} 220, \mathrm{Cd} 3 \mathcal{\varepsilon}$, and TER-119 markers by day 5 in culture, with a negligible $1.17 \pm 0.7 \%$ positivity for Gr1 marker and $~ 19 \%$ positivity for F4/80 marker [13].

For IR-conditioned media transfer studies, two sets of BM-EPCs from the same WT mice that were IR with ${ }^{1} \mathrm{H}$ or ${ }^{56} \mathrm{Fe}$ and Non-IR controls were prepared as described previously $[13,43]$. Upon attaining $70 \%$ confluence one set of BM-EPCs was exposed to $90 \mathrm{cGy}, 1 \mathrm{GeV}$ of ${ }^{1} \mathrm{H}$-IR and $15 \mathrm{cGy}$, and $1 \mathrm{GeV} / \mathrm{n}$ of ${ }^{56} \mathrm{Fe}$-IR. After irradiations conditioned media (CM) from ${ }^{1} \mathrm{H}$ - or ${ }^{56} \mathrm{Fe}$-IR-EPCs $\left({ }^{1} \mathrm{H}\right.$ - or ${ }^{56} \mathrm{Fe}$-IR$\mathrm{CM}$ ) and control Non-IR EPCs (Non-IR-CM) were collected at 2-, 5-, and 24-hour time points (Figure 1(a)). Prior to IR exposures, media were changed in all wells of both sets with fresh $3 \mathrm{~mL}$ of EBM-2 media without growth factors and incubated for 1 hour. The second set of Non-IR cells from the same mice was used as naïve (nonirradiated) EPCs for media transfer studies from their respective ${ }^{1} \mathrm{H}$-IR and ${ }^{56} \mathrm{Fe}$-IR exposed EPCs. ${ }^{1} \mathrm{H}$-IR- and ${ }^{56} \mathrm{Fe}-\mathrm{IR}$-CM were filtered through a sterile $0.22 \mu \mathrm{m}$ membrane syringe filter and $2 \mathrm{~mL}$ of IR-CM collected at 2, 5 and 24 hours after IR was added onto corresponding mice Non-IR EPCs. Non-IR-CM were also collected, filtered, and transferred similarly. Naïve EPCs were incubated for 24 hours with ${ }^{1} \mathrm{H}-,{ }^{56} \mathrm{Fe}$-, and NonIR conditioned media. EPCs from all three CM treatment conditions were collected at 2, 5, and 24 hours and processed 


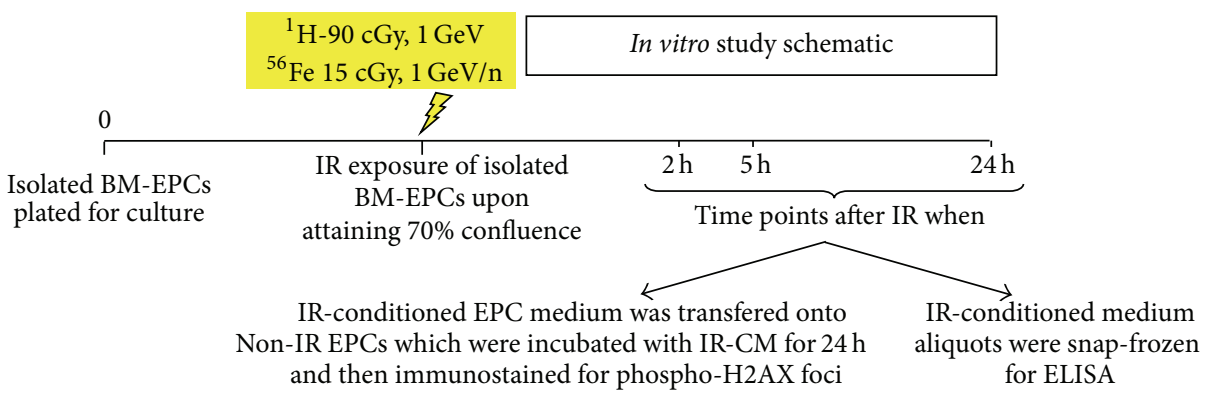

(a)

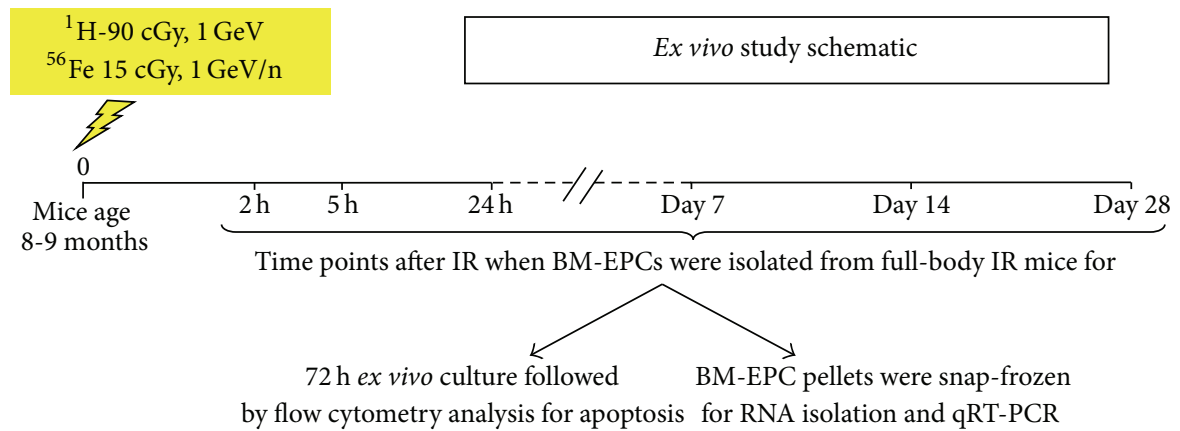

(b)

FIGURE 1: Diagrammatic representation of the experimental design to evaluate the effect of low-dose, whole body $90 \mathrm{cGy}, 1 \mathrm{GeV}{ }^{1} \mathrm{H}$ and $15 \mathrm{cGy}$, $1 \mathrm{GeV} / \mathrm{n}{ }^{56} \mathrm{Fe}-\mathrm{IR}$ in BM-derived EPCs of 8-10 months old C57BL/6NTac. (a) In vitro study schematic for IR-conditioned medium transfer study to evaluate bystander responses in nonirradiated BM-EPCs over 24-hour time period after IR. (b) Ex vivo study schematic to evaluate the effects of full-body IR over 28 days on survival of BM-EPCs.

for phosphorylated (p)-H2AX immunostaining as described below in Section 2.4. One $\mathrm{mL}$ of ${ }^{1} \mathrm{H}$-IR-, ${ }^{56} \mathrm{Fe}-\mathrm{IR}-$, and NonIR-CM was aliquoted and snap frozen in liquid nitrogen for protein analyses.

2.4. Immunofluorescent Staining. We assessed the formation and decay of p-H2AX foci in naïve EPCs treated for 24 hours with 2-, 5-, and 24-hour ${ }^{1} \mathrm{H}$-IR-, ${ }^{56} \mathrm{Fe}-\mathrm{IR}$-, and NonIR-CM EPCs. Cells on cover slips were washed with 1xPBS, fixed in $4 \%$ paraformaldehyde (PFA), and then incubated with primary anti-p-H2AX rabbit monoclonal antibody (Cat.9718S; Cell Signaling Technology, Danvers, MA). Alexa488 goat anti-rabbit secondary antibody (Cat.A11008; Life Technologies, Grand Island, NY) was used to assay p-H2AX foci formation and decay over time in Non-IR-, ${ }^{1} \mathrm{H}-\mathrm{IR}-$, and ${ }^{56}$ Fe-IR-CM-treated ex vivo expanded EPCs. Topro-3 was used to visualize nuclei (Cat.T3605; Life Technologies).

2.5. Confocal Microscopy and Analysis. Laser scanning confocal microscope (LSM 510 Meta, ZEISS, Thornwood, NY) was used to obtain immunofluorescent images at $\times 200$ magnification. The analyses of $\mathrm{p}-\mathrm{H} 2 \mathrm{AX}$ foci were performed using a computer assisted image analysis algorithm based on pixel and color distribution. Data analysis was performed using stringent constraint of not including cells with apoptotic features or micronuclei for $\mathrm{p}-\mathrm{H} 2 \mathrm{AX}$ analysis. All time points after ${ }^{1} \mathrm{H}$ and ${ }^{56} \mathrm{Fe}$-IR were plotted as percent cells with an $\mathrm{N}$ of $\mathrm{p}-\mathrm{H} 2 \mathrm{AX}$ foci compared to Non-IR controls and by quantifying cells with $\geq 2 \mathrm{p}-\mathrm{H} 2 \mathrm{AX}$ foci/cell.

2.6. Enzyme-Linked Immunosorbent Assay (ELISA). Conditioned media from BM-EPCs after ${ }^{1} \mathrm{H}-\mathrm{IR},{ }^{56} \mathrm{Fe}-\mathrm{IR}$, and Non-IR were collected at 2, 5, and 24 hours after IR and processed for mouse multiplex cytokine ELISA using manufacturer protocol (Signosis, Santa Clara, CA). Following 9 cytokines, chemokines and growth factors were analyzed: interleukin-1 alpha (IL- $1 \alpha$ ), interleukin-1 beta (IL-1 $\beta$ ), monocyte chemoattractant protein-1 (MCP-1), Rantes, microphage inflammatory protein-1 alpha (MIP- $1 \alpha$ ), granulocyte colonystimulating factor (G-CSF), granulocyte macrophage colonystimulating factor (GM-CSF), stem cell factor (SCF), and tumor necrosis factor- $\alpha$ (TNF- $\alpha)$. Absorbance readings at $450 \mathrm{~nm}$ were taken using Tecan Spectra model 96-well Microplate Reader (MTX Lab Systems, Vienna, VA) and data plotted using respective standard graphs obtained for each protein. Data analyzed was categorized into two separate groups: cytokines/chemokines and growth factors.

2.7. Apoptosis Assay of Ex Vivo Expanded BM-EPCs from ${ }^{1} \mathrm{H}$ and ${ }^{56} \mathrm{Fe}$ Full-Body Irradiated Mice over 28 Days. To assess the effects of ${ }^{1} \mathrm{H}$-IR and ${ }^{56} \mathrm{Fe}-\mathrm{IR}$ on survival of EPCs ex vivo, we isolated BM-EPCs from the total bone marrow of 
the full-body IR mice for short-term (2, 5, and 24 hours) and long-term (7, 14, and 28 days) time points after IR, as described in $[15,28,42]$ and in Section 2.3 (Figure 1(b)). Isolated BM-EPCs from each ${ }^{1} \mathrm{H}$-IR and ${ }^{56} \mathrm{Fe}$-IR mice were cultured for 72 hours ex vivo in EPC selective EBM-2 media supplemented with bullet kit growth factors (Lonza), on $15 \mathrm{~mm}$ circular glass coverslips (Electron Microscopy Sciences, Hatfield, PA) precoated with $0.2 \%$ gelatin in 24 -well dishes (Corning Inc.). At the end of 72 hours after initial seeding for both short- and long-term time points, BM-EPCs were trypsinized and harvested along with the supernatant growth media. No media change was done while BM-EPCs were in culture for 72 hours after seeding. Harvested cells were immunostained using Annexin V-FITC Apoptosis detection kit (eBiosciences Inc., San Diego, CA) as per manufacturer protocol and propidium iodide (final concentration $1 \mathrm{ug} / \mathrm{mL}$ ). Cells were analyzed by flow cytometry analysis to evaluate ${ }^{1} \mathrm{H}$ - or ${ }^{56} \mathrm{Fe}-\mathrm{IR}$ induced apoptosis in BM-EPCs. Annexin V was used to detect the cells in early stages of apoptosis and propidium iodide (PI) was used to identify necrotic cells. Data analyzed was plotted as percent (\%) change in double Annexin V/PI (+) cells for full-body ${ }^{1} \mathrm{H}$-IR and ${ }^{56} \mathrm{Fe}$-IR ex vivo selected BM-EPCs compared to Non-IR BM-EPCs that were set at $100 \%$.

2.8. Gene Expression Analysis and $q R T-P C R$. RNA from snap-frozen BM cells was isolated using RNeasy Mini Kit (QIAGEN, Valencia, CA). After isolation total RNA was converted to cDNA using the TaqMan Reverse Transcription Kit (Life technologies). qRT-PCR was performed on two genes (Bax and Bcl-2) that are known to play a significant role in the regulation of cell apoptosis. The samples were analyzed using Applied Biosystems 7300 Real Time PCR machine and software.

2.9. Statistical Analysis. All results were expressed as mean \pm SEM and plots were obtained. Statistical analysis was performed on the data by one-way ANOVA (Stat View Software, SAS Institute Inc.; Gary, NC). Differences were considered significant at $P<0.05$.

\section{Results}

3.1. Nonirradiated BM-Derived EPCs Treated with ${ }^{1} H$-IR and ${ }^{56} \mathrm{Fe}$-IR Conditioned Media Exhibit Radiobiological Bystanders Responses In Vitro. We determined whether non-IR BMEPCs may show evidence of bystander responses in media transfer experiment after treatment with ${ }^{1} \mathrm{H}$-IR and ${ }^{56} \mathrm{Fe}-$ IR conditioned BM-EPCs media as described before [13]. There was a steady and significant increase in the mean $\mathrm{p}$ H2AX foci/cell for Non-IR BM-EPCs treated with ${ }^{1} \mathrm{H}-\mathrm{IR}-$ CM. Compared to control CM-treated Non-IR BM-EPCs, there was 2-4-fold increase in the percent of cells with more than 4-11 p-H2AX foci/cell for ${ }^{1} \mathrm{H}$-IR-CM-treated cells (Figures 2(a) and 2(b)). There was less than $0.3 \%$ of cells with $12-16 \mathrm{p}-\mathrm{H} 2 \mathrm{AX}$ foci/cell in control CM-treated BM-EPC; whereas $1.5-4 \%$ of ${ }^{1} \mathrm{H}$-IR CM-treated naïve BM-EPC had 12-16 p-H2AX foci/cell. Furthermore, BM-EPCs treatment for 24 hours with 2, 5, and $24 \mathrm{~h}^{1} \mathrm{H}$-IR-CM revealed $0.3-$ $2 \%$ of cells with more than $17-23 \mathrm{p}-\mathrm{H} 2 \mathrm{AX}$ foci/cell versus no cells with 17-23 p-H2AX foci/cell in control Non-IRCM treated BM-EPCs (Figures 2(a) and 2(b)). These findings suggest that Non-IR BM-EPCs treated with ${ }^{1} \mathrm{H}$-IR-CM exhibit significant bystander responses up to 24 hours in vitro. We also determined the mean $\mathrm{p}-\mathrm{H} 2 \mathrm{AX}$ foci/cell induced in naïve BM-EPCs after 24-hour incubation with IR-CM at 2, 5, and 24-hour time point after IR. There was a steady and significant increase in mean $\mathrm{p}-\mathrm{H} 2 \mathrm{AX}$ foci/cell for naïve BMEPCs treated with IR-CM from ${ }^{1} \mathrm{H}$-IR BM-EPCs at every time point compared to EPCs treated with Non-IR-CM, with a $\sim 400 \%$ increase for 24 hour post-IR-CM treated naïve EPCs (Figure 2(c)).

Compared to control Non-IR CM-treated BM-EPCs, there was 2-4-fold increase in the percent of cells with more than 3-10 p-H2AX foci/cell for ${ }^{56} \mathrm{Fe}-\mathrm{IR}-\mathrm{CM}$-treated cells (Figures 3(a) and 3(b)). Furthermore, only ${ }^{56} \mathrm{Fe}-\mathrm{IR} \mathrm{CM}-$ treated BM-EPCs revealed $0.3-1.3 \%$ of cells with more than 11-17 p-H2AX foci/cell at 2, 5, and 24 hours after treatment (Figures 3(a) and 3(b)). These findings suggest that Non-IR BM-EPCs treated ${ }^{56} \mathrm{Fe}-\mathrm{IR}-\mathrm{CM}$ exhibit significant bystander responses up to 24 hours in vitro. We also determined the mean p-H2AX foci/cell induced in naïve BM-EPCs after 24hour incubation with IR-CM at 2, 5, and 24-hour time point after ${ }^{56} \mathrm{Fe}$-IR. There was a significant increase in mean $\mathrm{p}$ $\mathrm{H} 2 \mathrm{AX}$ foci/cell for naïve BM-EPCs treated with ${ }^{56} \mathrm{Fe}-\mathrm{IR}-\mathrm{CM}$ at every time point compared to EPCs treated with Non-IRCM, with a $\sim 160 \%$ increase for $2-24$ hour post-IR-CM treated naïve EPCs (Figure 3(c)). It should be noted that the percent of mean $\mathrm{pH} 2 \mathrm{AX}$ foci/cell in ${ }^{56} \mathrm{Fe}-\mathrm{IR}-\mathrm{CM}$ treated naïve EPC was twice as low compared to ${ }^{1} \mathrm{H}-\mathrm{IR}-\mathrm{CM}$ treated naïve EPCs. This finding could be directly attributed to significant cell death observed in ${ }^{56} \mathrm{Fe}-\mathrm{IR}-\mathrm{CM}$ treated EPCs over 24 hours (data not shown).

\subsection{Inflammatory Cytokines Are Significantly Increased in ${ }^{1} \mathrm{H}$ -} IR and ${ }^{56} \mathrm{Fe}$-IR Conditioned Medium. In 2006 Bubici et al., demonstrated that the convergence of IR-mediated effects results in inflammation due to increased levels of various cytokines and chemokines that generate reactive oxygen and nitrogen species [44]. We sought to determine the effect of ${ }^{1} \mathrm{H}$-IR on production and accumulation of cytokines, chemokines, and growth factors, such as IL- $1 \alpha$, IL- $1 \beta$, MCP1, MIP- $1 \alpha$, Rantes, G-CSF, GM-CSF, and SCF in BM-EPCs, all of which are known to be elevated within minutes to hours after IR [4]. ELISA analysis of conditioned media from ${ }^{1} \mathrm{H}-\mathrm{IR}$ BM-EPCs showed a gradual increase in the levels of several cytokines, chemokines, and growth factor, when compared to Non-IR-CM. The maximum and statistically significant increases (2-53-fold) in IL-1 $\alpha$, MCP-1, Rantes, G-CSF, GMCSF, and SCF were observed in the culture media of ${ }^{1} \mathrm{H}$ IR BM-EPCs at 24 hours (Figures 4(a), 4(c)-4(e), 4(g), and $4(\mathrm{~h})$ and Table 1$)$. Although, IL- $1 \beta$ and MIP- $1 \alpha$ levels in ${ }^{1} \mathrm{H}$-IR BM-EPC culture media were slightly elevated ( 39$136 \%$ ) by 24 hours, it was not significant when compared to Non-IR EPC media (Figures 4(b) and 4(f) and Table 1). These findings suggest that in BM-EPCs, ${ }^{1} \mathrm{H}-\mathrm{IR}$ at $90 \mathrm{cGy}$ 


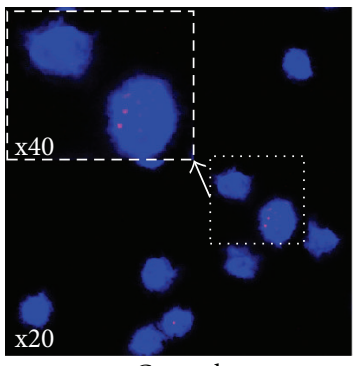

Control

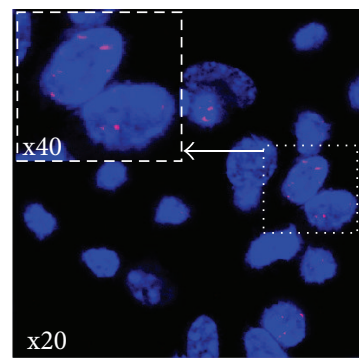

2

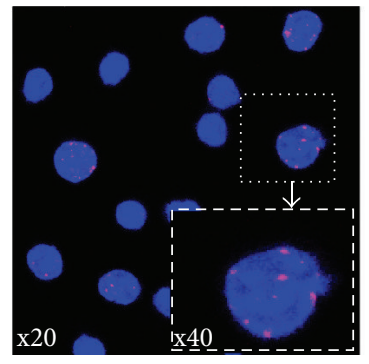

5

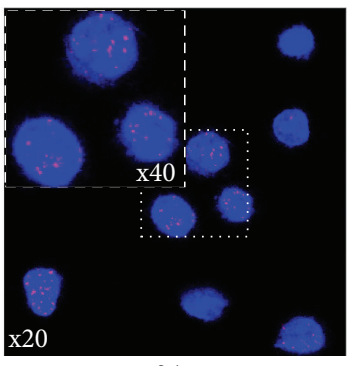

24

Hours after adding ${ }^{1} \mathrm{H}$-IR conditioned media

(a)

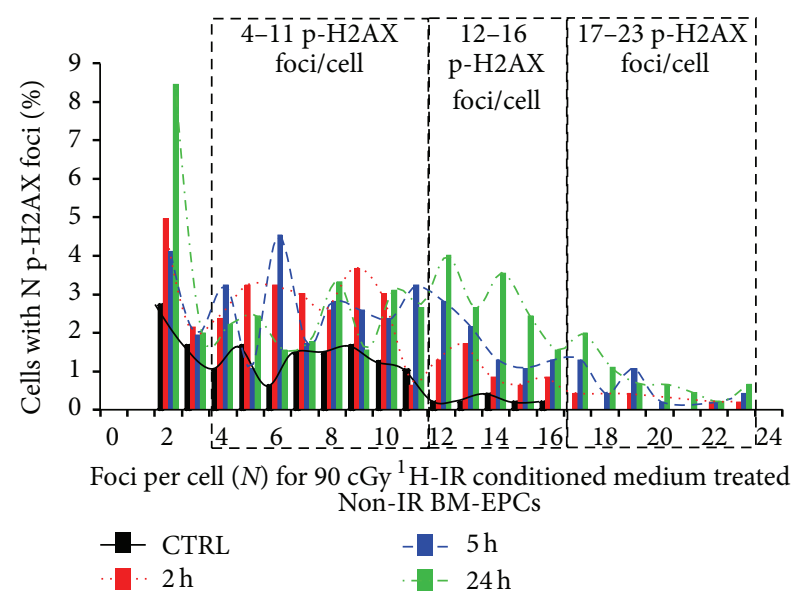

(b)

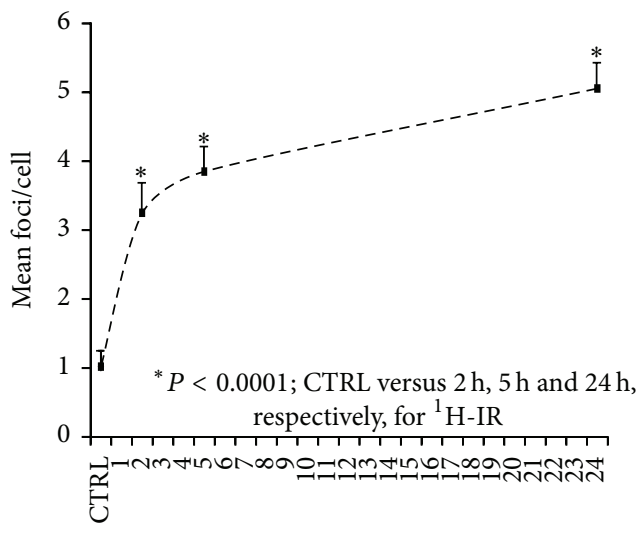

Hours after collection of conditioned medium from $90 \mathrm{cGy}{ }^{1} \mathrm{H}$-IR EPCs

(c)

FIgURE 2: Nonirradiated BM-EPCs treated with ${ }^{1} \mathrm{H}$-IR conditioned media exhibit increased number of p-H2AX foci/cell in vitro. (a) Representative confocal images of p-H2AX $24 \mathrm{~h}$ after treatment of Non-IR BM-EPCs with ${ }^{1} \mathrm{H}$-IR-CM medium collected from duplicate set of respective BM-EPCs 2, 5, and 24 hours after $90 \mathrm{cGy}{ }^{1} \mathrm{H}$-IR. (b) Mean p-H2AX foci distribution (with $\geq 2 \mathrm{p}-\mathrm{H} 2 \mathrm{AX}$ foci/cell) in BM-EPCs treated with Non-IR and ${ }^{1} \mathrm{H}$-IR conditioned media (CM). Foci distribution plot for $\%$ of Non-IR BM-EPCs with a given number $(N)$ of foci after treatment for $24 \mathrm{~h}$ with CM from $90 \mathrm{cGy}{ }^{1} \mathrm{H}$-IR BM-EPCs at $2 \mathrm{~h}$ (red bars and dotted lines), $5 \mathrm{~h}$ (blue bars and dashed lines), and $24 \mathrm{~h}$ (green bars and dashed/dotted lines) compared to Non-IR controls (black bars and solid lines). For clarity of data presentation and due to no difference in the number of $\mathrm{p}-\mathrm{H} 2 \mathrm{AX}$ foci/cell between Non-IR and ${ }^{1} \mathrm{H}$-IR treatment groups, graphs represent distribution of p-H2AX foci/cell after excluding the cells with zero and 1 foci/cell. (c) Mean p-H2AX foci/cell plotted for control, $2 \mathrm{~h}, 5 \mathrm{~h}$, and $24 \mathrm{~h}$ time points after treatment of Non-IR BM-EPC with ${ }^{1} \mathrm{H}$-IR CM. Graphs represent mean \pm SEM of the pooled data from 5-6 independent biological samples/experiments. Statistical significance was assigned when $P<0.05$.

TABLE 1: Represents \% change and statistical significance values in cumulative levels of cytokine, chemokine, and growth factors collected $24 \mathrm{~h}$ after treatment with ${ }^{1} \mathrm{H}-\mathrm{IR}-\mathrm{CM}$, for control versus day 1.

\begin{tabular}{|c|c|c|c|c|c|c|c|c|}
\hline \multirow{2}{*}{${ }^{1} \mathrm{H}-\mathrm{IR}-\mathrm{CM}$} & \multicolumn{4}{|c|}{ Cytokines and chemokines } & \multicolumn{4}{|c|}{ Growth factors } \\
\hline & IL- $1 \alpha$ & IL-1 $\beta$ & MCP-1 & MIP- $1 \alpha$ & Rantes & G-CSF & GM-CSF & SCF \\
\hline $\begin{array}{l}\text { CTRL versus } 1 \\
\text { day } \\
\% \text { increase }\end{array}$ & $1541 \% \uparrow$ & $136 \% \uparrow$ & $197 \% \uparrow$ & $39 \% \uparrow$ & $486 \% \uparrow$ & $5337 \% \uparrow$ & $324 \% \uparrow$ & $271 \% \uparrow$ \\
\hline $\begin{array}{l}\text { CTRL versus } 1 \\
\text { day } \\
P \text { value }\end{array}$ & ${ }^{* * *} P<0.0003$ & & ${ }^{*} P<0.05$ & & ${ }^{* *} P<0.002$ & ${ }^{* * *} P<0.0001$ & ${ }^{* * *} P<0.007$ & ${ }^{* *} P<0.002$ \\
\hline
\end{tabular}

Asterisk corresponds to the respective plots for cumulative levels of inflammatory cytokines and chemokines in ${ }^{1} \mathrm{H}$-IR conditioned medium (Figure 4 ). 


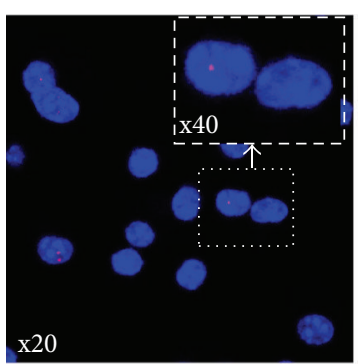

Control

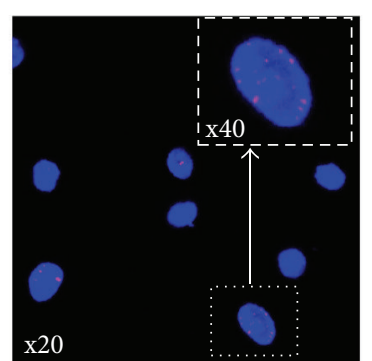

2

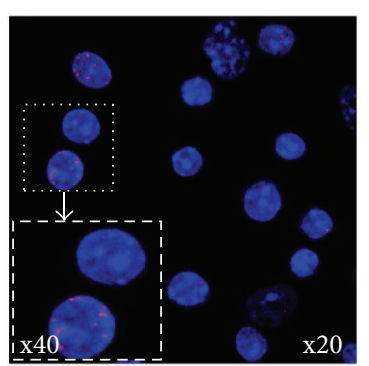

5

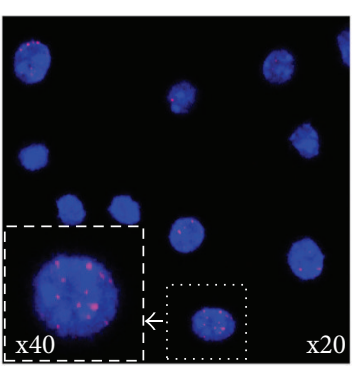

24

Hours after adding ${ }^{56} \mathrm{Fe}$-IR conditioned media

(a)

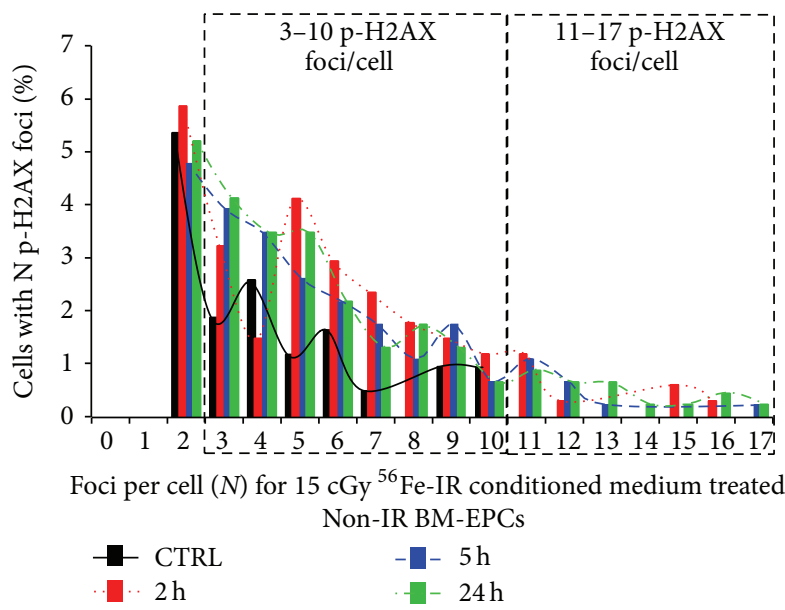

(b)

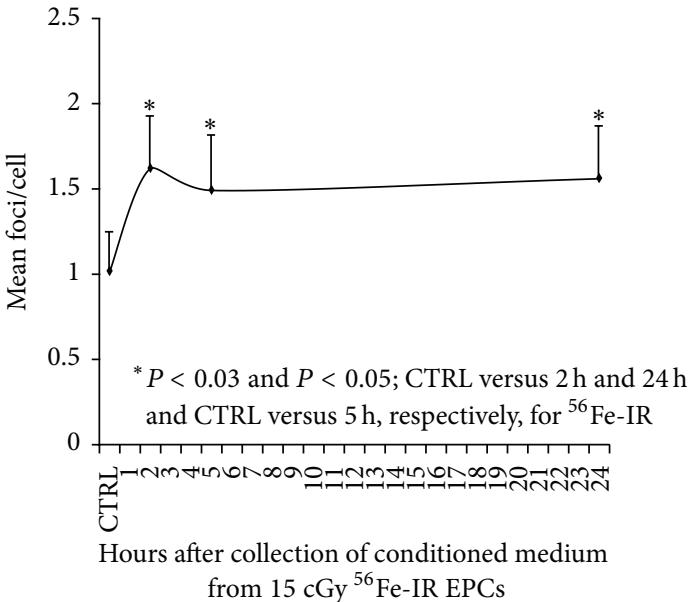

(c)

FIgure 3: Nonirradiated BM-EPCs treated with ${ }^{56} \mathrm{Fe}-\mathrm{IR}$ conditioned media exhibit increased number of p-H2AX foci/cell in vitro. (a) Representative confocal images of p-H2AX $24 \mathrm{~h}$ after treatment of Non-IR BM-EPCs with ${ }^{56} \mathrm{Fe}-\mathrm{IR}$-CM medium collected from duplicate set of respective EPCs 2, 5, and $24 \mathrm{~h}$ after $15 \mathrm{cGy}{ }^{56} \mathrm{Fe}$-IR. (b) Mean p-H2AX foci distribution (with $\geq 2 \mathrm{p}-\mathrm{H} 2 \mathrm{AX}$ foci/cell) in BM-EPCs treated with Non-IR- and ${ }^{56} \mathrm{Fe}$-IR conditioned media (CM). Foci distribution plot for $\%$ of Non-IR BM-EPCs with a given number $(N)$ of foci after treatment for $24 \mathrm{~h}$ with CM from $15 \mathrm{cGy}{ }^{56} \mathrm{Fe}$-IR BM-EPCs at $2 \mathrm{~h}$ (red bars and dotted lines), $5 \mathrm{~h}$ (blue bars and dashed lines), and $24 \mathrm{~h}$ (green bars and dashed/dotted lines) compared to Non-IR controls (black bars and solid lines). Due to no difference in the number of p-H2AX foci/cell between Non-IR and ${ }^{56} \mathrm{Fe}-\mathrm{IR}$ treatment groups, graph represents distribution of $\mathrm{p}-\mathrm{H} 2 \mathrm{AX}$ foci/cell after excluding the cells with zero and 1 foci/cell. (c) Mean p-H2AX foci/cell plotted for control, $2 \mathrm{~h}, 5 \mathrm{~h}$, and $24 \mathrm{~h}$ treatment time point after treatment of BM-EPCs with ${ }^{56} \mathrm{Fe}-\mathrm{IR}$ $\mathrm{CM}$. Graphs represent mean \pm SEM of the pooled data from 5 to 6 independent biological samples/experiments. Statistical significance was assigned when $P<0.05$.

induces accumulation of several cytokines and growth factors that have been directly implicated in mediating bystander responses in BM-derived EPCs [11, 13].

Similar to studies with ${ }^{1} \mathrm{H}$-IR BM-EPCs we also determined the accumulation of cytokines, chemokines, and growth factors in the media of BM-EPCs irradiated with $15 \mathrm{cGy}, 1 \mathrm{GeV} / \mathrm{n}$ of ${ }^{56} \mathrm{Fe}$-IR. ELISA analysis of conditioned media from ${ }^{56} \mathrm{Fe}-\mathrm{IR}$ BM-EPCs showed a gradual increase in the levels of several cytokines, chemokines, and growth factor, when compared to Non-IR-CM. Maximum and statistically significant increase (1.4-22-fold) in IL- $1 \alpha$, MCP-1, MIP-1 $\alpha$, Rantes, G-CSF, GM-CSF, and SCF was observed by 24 hours (Figure $5(\mathrm{a})$ and $5(\mathrm{c})-5(\mathrm{~h})$ and Table 2). Although, IL-1 $\beta$ level in ${ }^{56} \mathrm{Fe}-\mathrm{IR}$ EPC media were slightly elevated $(\sim$ $40 \%$ ) by 24 hours, it was not significant when compared to Non-IR EPC media (Figure 5(b) and Table 2). These findings suggest that ${ }^{56} \mathrm{Fe}-\mathrm{IR}$ at $15 \mathrm{cGy}$ induces accumulation of several cytokines and growth factors that have been directly implicated in mediating bystander responses [11, 13].

\subsection{Full-Body ${ }^{1} \mathrm{H}$-IR and ${ }^{56} \mathrm{Fe}-\mathrm{IR}$ Induce Cyclical Increases} in BM-EPC Apoptosis over 28 Days after IR. To determine the effect of full-body ${ }^{1} \mathrm{H}$-IR on ex vivo apoptosis, MNC isolated from total bone marrow were plated in 24-well plates at 2, 5, and 24 hours and 7, 14, and 28 days after ${ }^{1} \mathrm{H}$-IR. BM-EPC apoptosis was determined 72 hours after plating using flow cytometry analysis of BM-EPCs double stained with Annexin $\mathrm{V}$ and propidium iodide. Our results revealed that compared to control Non-IR BM-EPCs, in fullbody ${ }^{1} \mathrm{H}$-IR EPCs cultured for 72 hours ex vivo there was $50 \%$ and $350 \%$ increases in BM-EPC apoptosis at 5 and 24 hours, respectively (Figure 6(a)). By day 7 the apoptosis was decreased to near control Non-IR levels. However, there was 


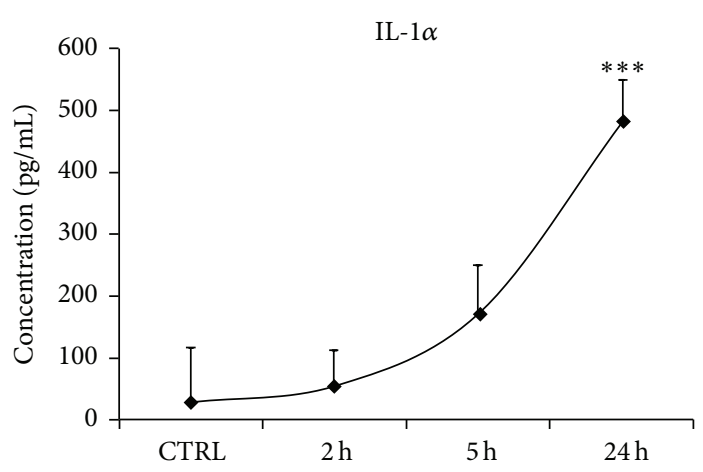

(a)

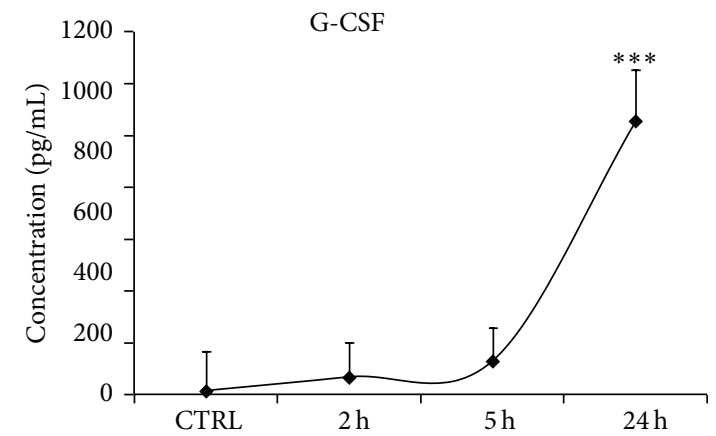

(c)

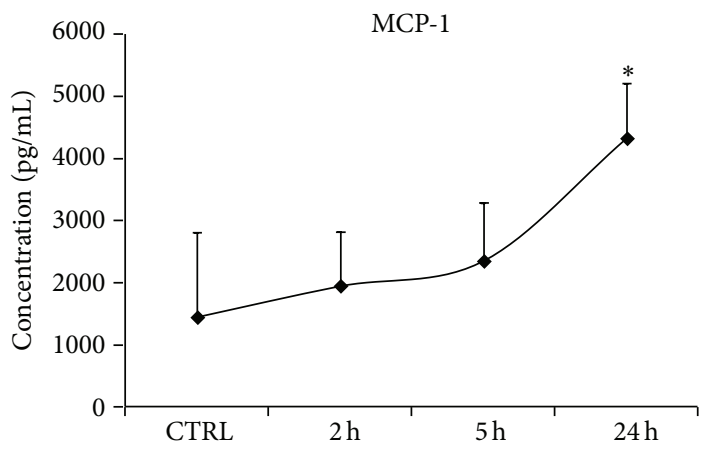

(e)

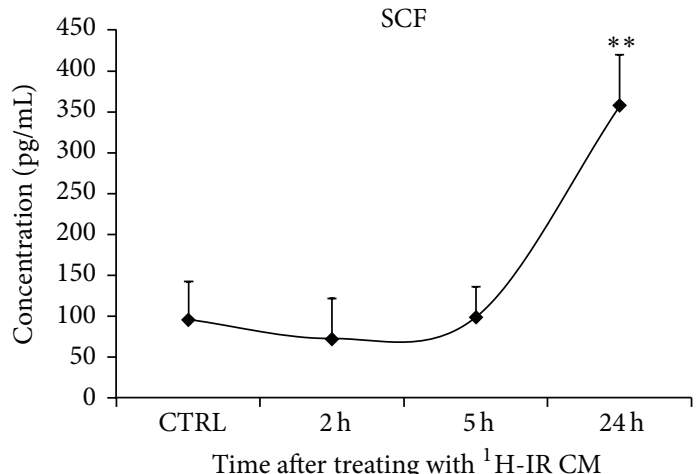

(g)

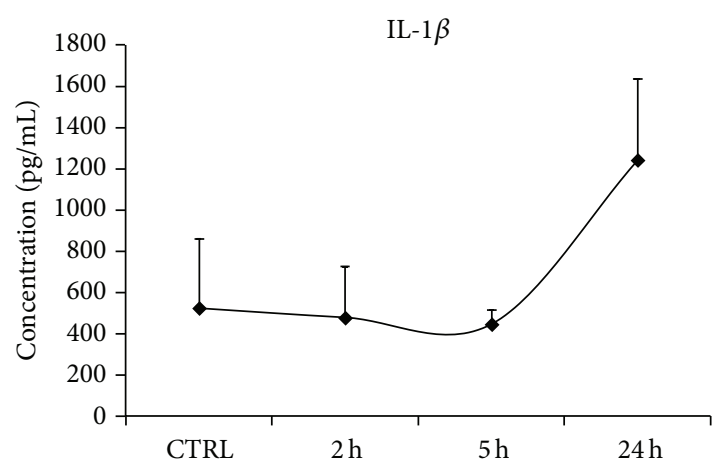

(b)

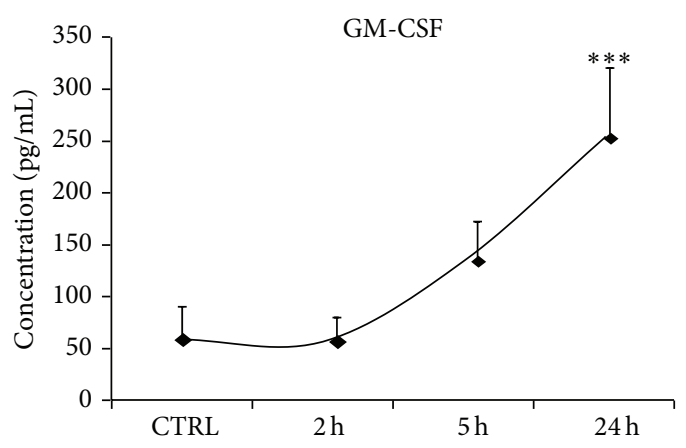

(d)

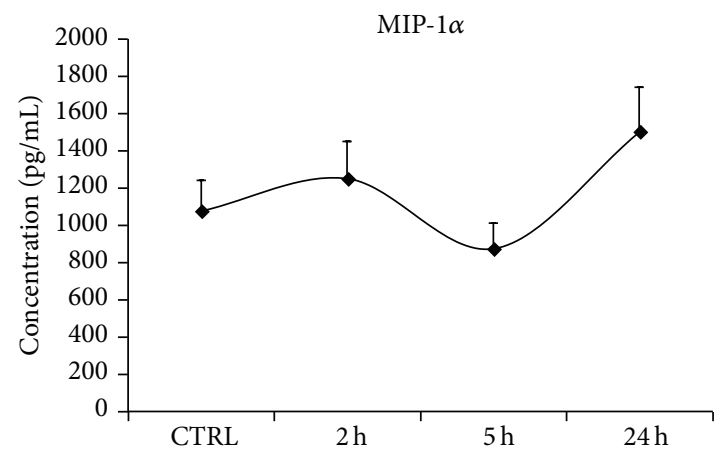

(f)

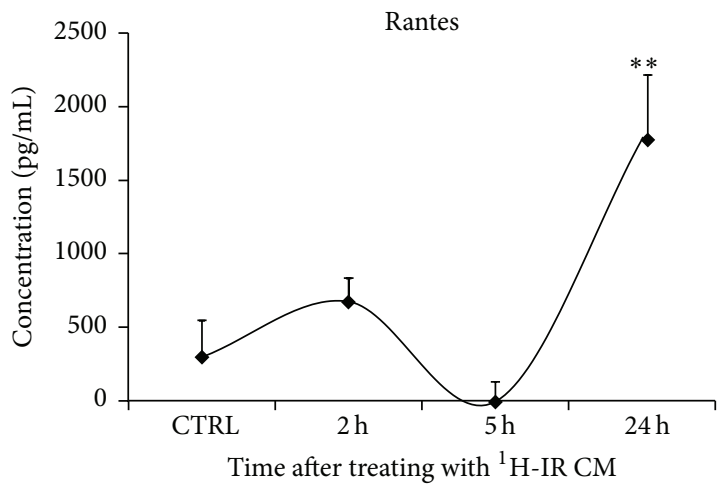

(h)

FIGURE 4: Cumulative levels of inflammatory cytokines and chemokines are significantly increased in ${ }^{1} \mathrm{H}$-IR conditioned medium. Graphic representation of IR-induced increases in the cumulative concentration $(\mathrm{pg} / \mathrm{mL})$ of cytokines, chemokines, and growth factors in CM from $90 \mathrm{cGy}{ }^{1} \mathrm{H}$-IR BM-EPCs in vitro at 2, 5, and $24 \mathrm{~h}$ after IR for (a) IL- $1 \alpha$, (b) IL-1 $\beta$, (c) G-CSF, (d) GM-CSF, (e) MCP-1, (f) MIP-1 $\alpha$, (g) SCF, and (h) Rantes. Graphs represent mean \pm SEM of the pooled data from 3 independent biological samples/experiments. Statistical significance was assigned when $P<0.05$. 


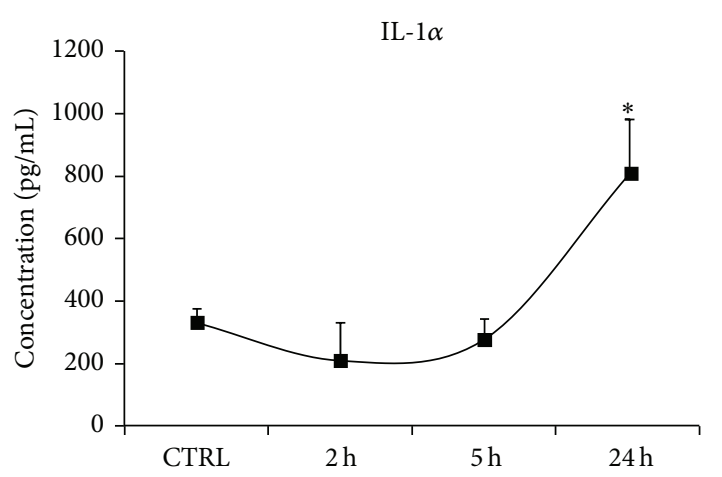

(a)

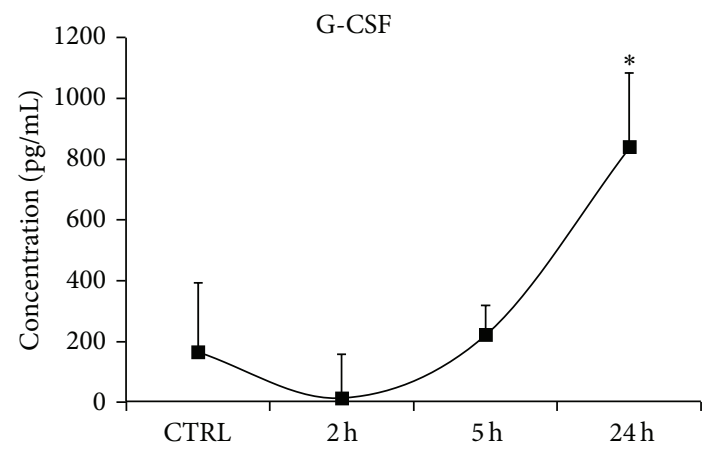

(c)

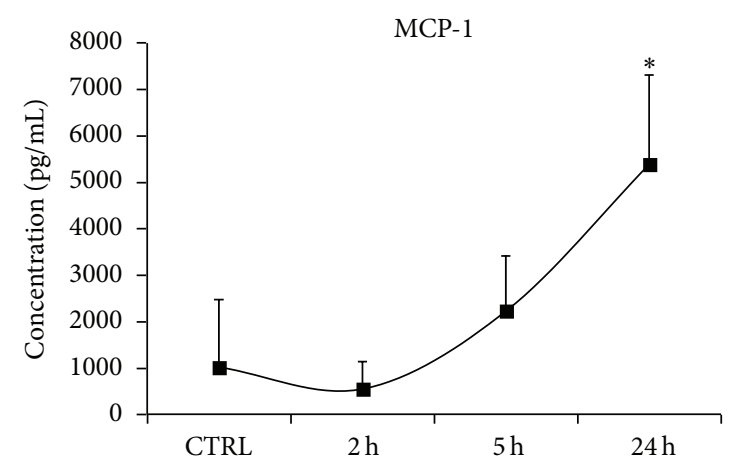

(e)

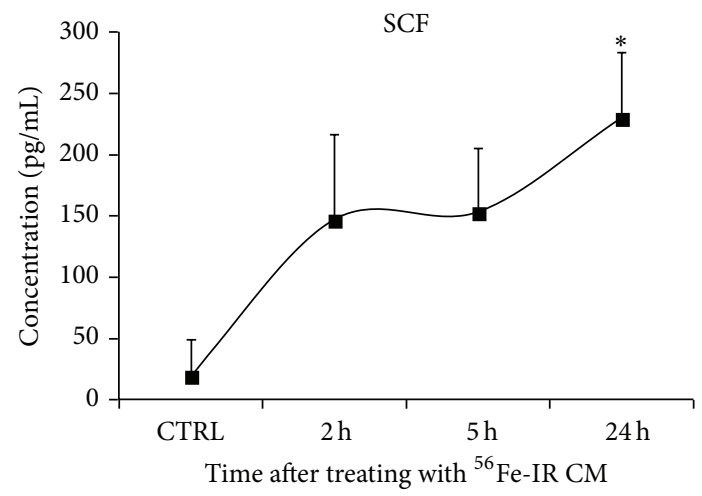

(g)

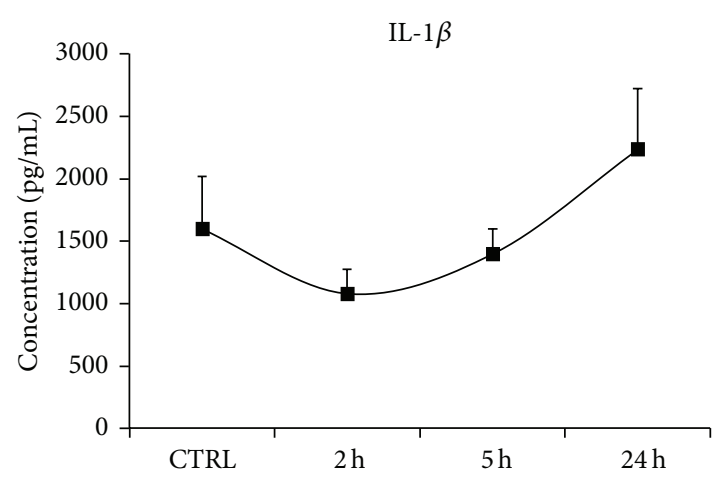

(b)

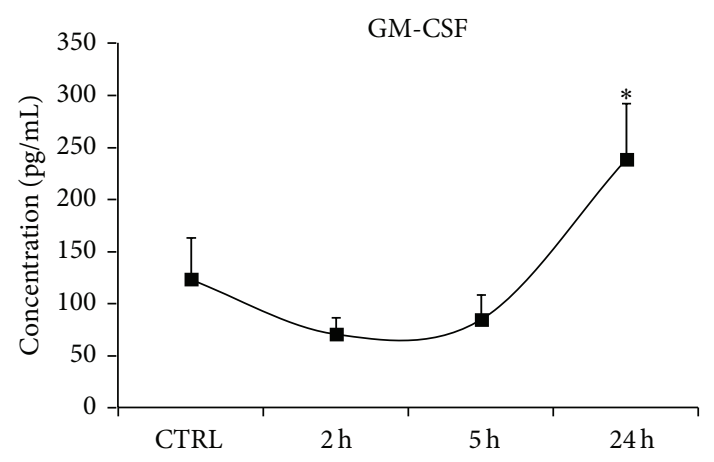

(d)

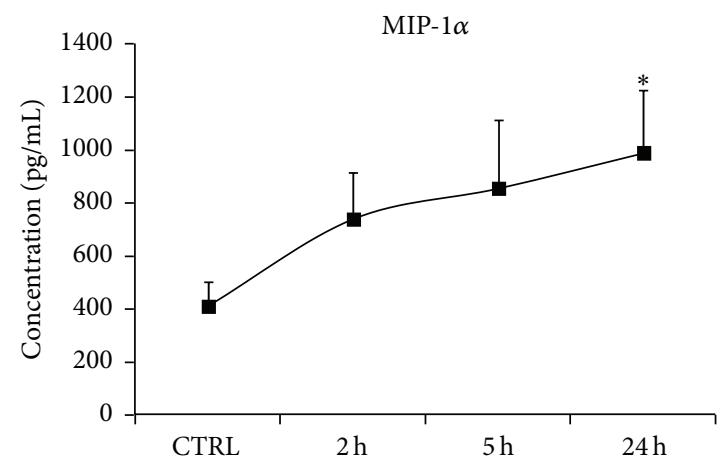

(f)

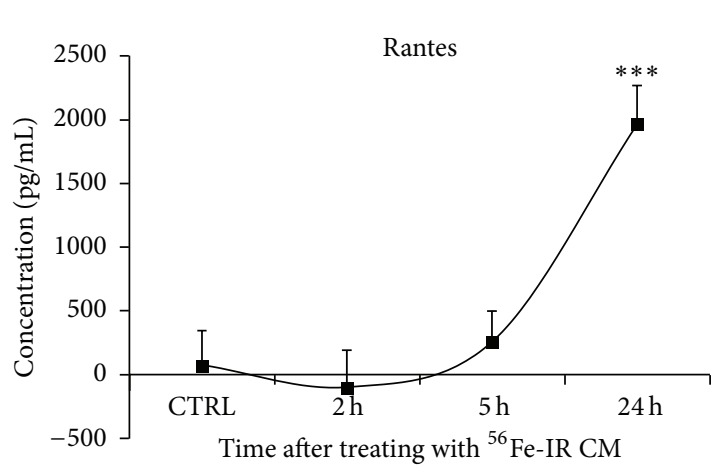

(h)

FIGURE 5: Cumulative levels of inflammatory cytokines and chemokines are significantly increased in ${ }^{56} \mathrm{Fe}-\mathrm{IR}$ conditioned medium. Graphic representation of IR-induced increase in the cumulative concentration $(\mathrm{pg} / \mathrm{mL})$ of cytokines, chemokines, and growth factors in CM from $15 \mathrm{cGy}{ }^{56} \mathrm{Fe}-\mathrm{IR}$ BM-EPCs in vitro at 2, 5 and 24 hours post-IR for (a) IL-1 $\alpha$, (b) IL-1 $\beta$, (c) G-CSF, (d) GM-CSF, (e) MCP-1, (f) MIP-1 $\alpha$, (g) SCF, and (h) Rantes. Graphs represent mean \pm SEM of the pooled data from 3 independent biological samples/experiments. Statistical significance was assigned when $P<0.05$. 
TABLE 2: Represents \% change and statistical significance values in cumulative levels of cytokine, chemokine, and growth factors collected $24 \mathrm{~h}$ after treatment with ${ }^{56} \mathrm{Fe}-\mathrm{IR}-\mathrm{CM}$, for control versus day 1.

\begin{tabular}{|c|c|c|c|c|c|c|c|c|}
\hline \multirow{2}{*}{${ }^{56} \mathrm{Fe}-\mathrm{IR}-\mathrm{CM}$} & \multicolumn{4}{|c|}{ Cytokines and chemokines } & \multicolumn{4}{|c|}{ Growth factors } \\
\hline & IL- $1 \alpha$ & IL-1 $\beta$ & MCP-1 & MIP-1 $\alpha$ & Rantes & G-CSF & GM-CSF & SCF \\
\hline $\begin{array}{l}\text { CTRL versus } 1 \\
\text { day } \\
\% \text { increase }\end{array}$ & $141 \% \uparrow$ & $40 \% \uparrow$ & $413 \% \uparrow$ & $140 \% \uparrow$ & $2230 \% \uparrow$ & $402 \% \uparrow$ & $92 \% \uparrow$ & $1107 \% \uparrow$ \\
\hline $\begin{array}{l}\text { CTRL versus } 1 \\
\text { day } \\
P \text { value }\end{array}$ & ${ }^{*} P<0.02$ & & ${ }^{*} P<0.04$ & ${ }^{*} P<0.04$ & ${ }^{* * *} P<0.0001$ & ${ }^{*} P<0.02$ & ${ }^{*} P<0.04$ & ${ }^{*} P<0.02$ \\
\hline
\end{tabular}

Asterisk corresponds to the respective plots for cumulative levels of inflammatory cytokines and chemokines in ${ }^{56} \mathrm{Fe}-\mathrm{IR}$ conditioned medium (Figure 5).

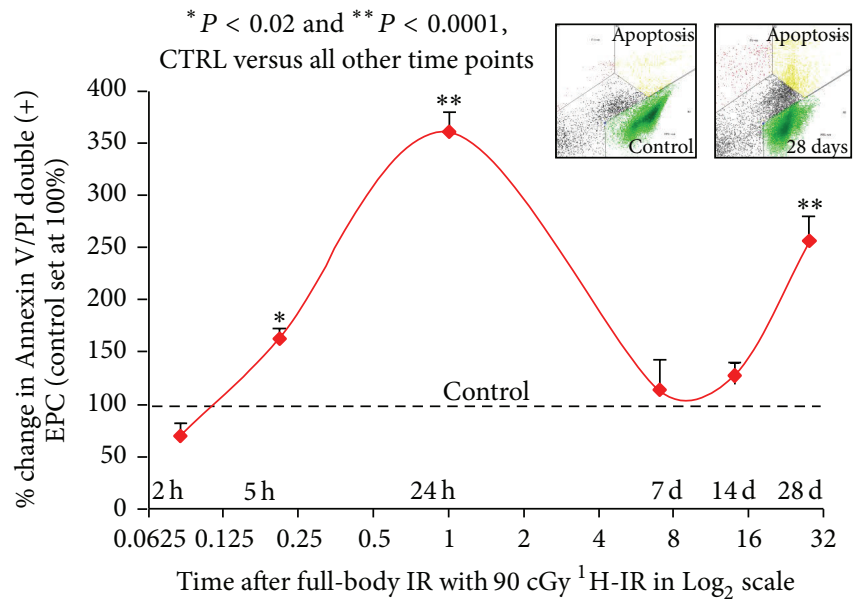

(a)

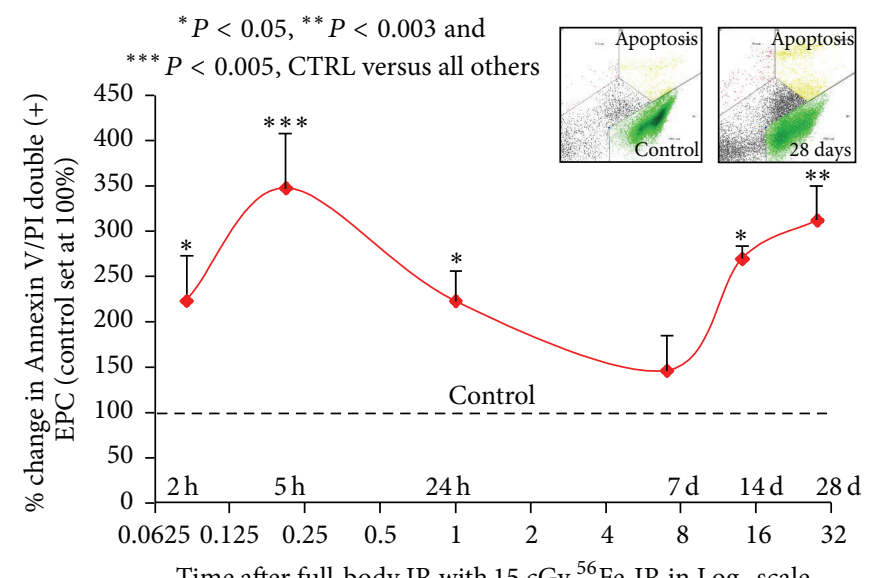

Time after full-body IR with $15 \mathrm{cGy}{ }^{56} \mathrm{Fe}$-IR in $\log _{2}$ scale

(c)

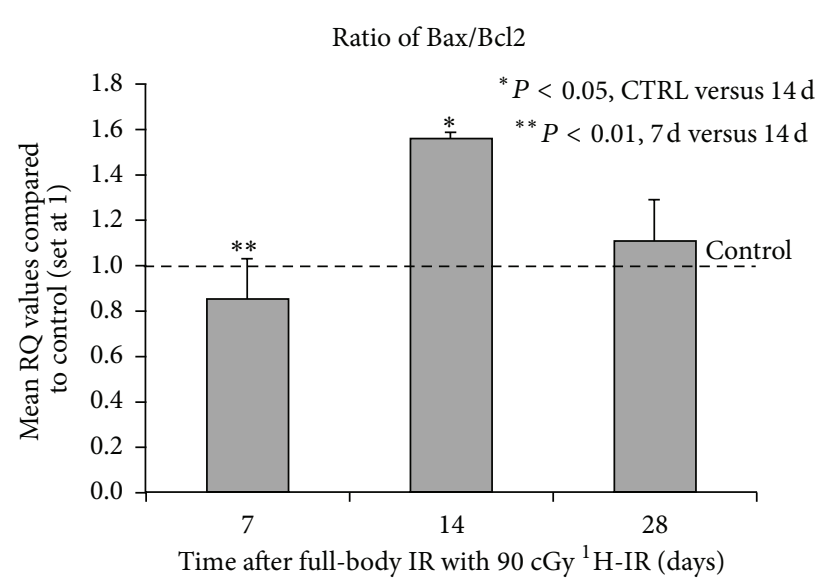

(b)

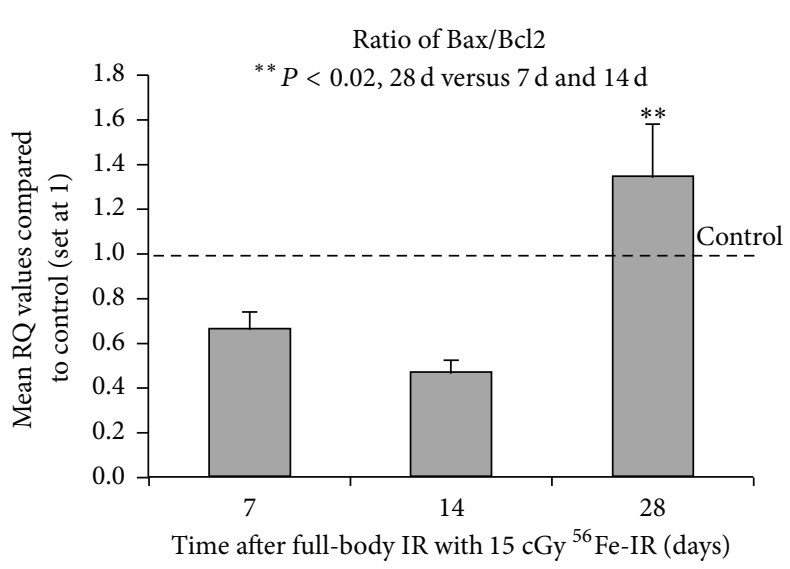

(d)

FIGURE 6: Full-body ${ }^{1} \mathrm{H}$-IR and ${ }^{56} \mathrm{Fe}-\mathrm{IR}$ induces early (2-24 h) and delayed (14-28 days) apoptosis in BM-EPCs ex vivo. Graphic representation of mean \% change in Annexin V and propidium iodide (P.I) double positive (+) BM-EPCs cultured ex vivo for $72 \mathrm{~h}$ (solid red line) after fullbody single-dose IR of (a) $90 \mathrm{cGy}{ }^{1} \mathrm{H}$-IR mice and (c) $15 \mathrm{cGy}{ }^{56} \mathrm{Fe}$-IR mice at 2, 5, and 24 hours and 7, 14, and 28 days after IR. The corresponding control for each time point was set at $100 \%$. Insets in (a) and (c) are representative flow cytometry analysis plots for corresponding control and 28-day time points. Graphic representation of qRT-PCR analysis, mean RQ values compared to control (which was set at 1) of BM-EPCs from full-body single-dose IR of (b) $90 \mathrm{cGy}{ }^{1} \mathrm{H}$-IR mice and (d) $15 \mathrm{cGy}{ }^{56} \mathrm{Fe}-\mathrm{IR}$ mics at 7, 14, and 28 days after IR for ratio of Bax/Bcl2. The corresponding control for each time point was set at 1 . Graphs represent mean \pm SEM of the pooled data from 5-6 independent biological samples/experiments. Statistical significance was assigned when $P<0.05$. 
a second $250 \%$ increase in BM-EPC apoptosis in ${ }^{1} \mathrm{H}$-IR EPCs on day 28 (Figure 6(a)). This data indicates that there is a cyclical increase, early at 5 hours and delayed at 28 days, in BM-EPC apoptosis after a single full-body low-dose ${ }^{1} \mathrm{H}$-IR.

Accordingly, flow cytometry analysis of Annexin V/PI double positive cells revealed that 2, 5, and 24 hours after full-body ${ }^{56} \mathrm{Fe}$-IR there was $250-350 \%$ increase in BM-EPC apoptosis, with the peak $350 \%$ increases in apoptosis after ${ }^{56} \mathrm{Fe}-\mathrm{IR}$ at 5 hours (Figure $6(\mathrm{c})$ ). By day 7 the apoptosis in ${ }^{56} \mathrm{Fe}-\mathrm{IR}$ BM-EPCs was decreased to near control Non-IR levels. However, there was a gradual increase in BM-EPC apoptosis in ${ }^{56} \mathrm{Fe}-\mathrm{IR}$ mice between days 14 and 28, with maximum $320 \%$ increase in apoptosis on day 28 (Figure 6(c)). This data indicates that there is a cyclical increase, early at 5 hours and delayed at 28 days, in BM-EPC apoptosis after a single full-body low-dose ${ }^{56} \mathrm{Fe}-\mathrm{IR}$.

3.4. ${ }^{1} \mathrm{H}-\mathrm{IR}$ and ${ }^{56} \mathrm{Fe}-\mathrm{IR}$ Modifies Expression of Cell Cycle and Apoptosis Regulating Genes in BM-EPCs Ex Vivo. To determine whether full body ${ }^{1} \mathrm{H}$-IR may affect expression of Bax and Bcl-2 (two well-known regulators of survival and apoptosis) $[45,46]$, total RNA from ${ }^{1} \mathrm{H}$-IR BM-EPCs were processed for qRT-PCR. Because early effects of IR may be a nonspecific global shut-down of transcription and translation [47] we examined the gene expression in our samples at the later time points, that is, 7, 14, and 28 days after ${ }^{1} \mathrm{H}$-IR. Because the ratio of Bax protein, an inducer of apoptosis, to $\mathrm{Bcl}-2$ protein, an inhibitor of apoptosis, could regulate survival or apoptosis after a stimulus, such as, ionizing radiation $[48,49]$, we evaluated the ratio of $\mathrm{Bax} / \mathrm{Bcl}-2$ expression. The ratio of Bax to $\mathrm{Bcl}-2$ was decreased $\sim 20 \%(P<0.01)$ on day 7 , which coincided with a significant decrease in BM-EPC apoptosis on day 7 compared to $24 \mathrm{~h}$ after ${ }^{1} \mathrm{H}$ IR (Figure 6(a)). There was $\sim 60 \%(P<0.05)$ increase in $\mathrm{Bax} / \mathrm{Bcl}-2$ ratio on day 14 after ${ }^{1} \mathrm{H}$-IR (Figure 6(b)) which coincided with the beginning of the increase in apoptosis in ${ }^{1} \mathrm{H}$-IR BM-EPCs between 14 and 28 days (Figure 6(a)). These results suggest, at least in part, the increase in the ratio of Bax/Bcl-2 expression may be responsible for induction of apoptosis in ${ }^{1} \mathrm{H}$-IR BM-EPCs.

As for ${ }^{1} \mathrm{H}$-IR BM-EPCs, we also examined the gene expression in ${ }^{56} \mathrm{Fe}-\mathrm{IR}$ BM-EPCs samples at 7, 14, and 28 days after ${ }^{56} \mathrm{Fe}-\mathrm{IR}$. The ratio of Bax to Bcl-2 was decreased $~ 65 \%$ on day 7 (Figure 6(d)), which coincided with a significant decrease in BM-EPC apoptosis on day 7 compared to 5 and $24 \mathrm{~h}$ after ${ }^{56} \mathrm{Fe}-\mathrm{IR}$ (Figure 6(c)). There was a further $\sim 15 \%$ decrease in Bax/Bcl-2 ratio on day 14 after ${ }^{56} \mathrm{Fe}$-IR (Figure 6(d)). However, compared to 7 and 14 days, there was more than 2-fold $(P<0.02)$ increase in the $\mathrm{Bax} / \mathrm{Bcl}-2$ ratio on day 28 (Figure 6(d)), which correlated with significant increase in apoptosis in ${ }^{56} \mathrm{Fe}$-IR BM-EPCs on day 28 after IR (Figure 6(c)). These results suggest at least in part the increase in ratio of $\mathrm{Bax} / \mathrm{Bcl}-2$ expression may be responsible for induction of apoptosis in ${ }^{56} \mathrm{Fe}-\mathrm{IR}$ BM-EPCs on day 28. However, increased apoptosis on day 14 may not be associated with the changes in the regulation of mitochondrial proteins, such as Bax and Bcl-2.

\section{Discussion}

A growing body of evidence indicates that in the heart and other organ-tissues vascular homeostasis does not exclusively rely on proliferation of local endothelial cells (ECs) but also involves BM-derived EPCs [50]. Indeed, studies have demonstrated that in patients with $\mathrm{CV}$ risk factors, the number and migratory ability of EPCs isolated from peripheral blood is reduced [51] and EPC function is impaired [52]. In addition, a strong inverse correlation was reported between the number of circulating EPCs, vascular function, and the subject's combined Framingham CV factor score [53]. Furthermore, measurements of flow-mediated brachialartery reactivity also revealed a significant relation between endothelial function and the number of EPCs, supporting a role for EPCs in the maintenance of endothelial integrity [54].

It is established that EPCs mobilized from the bone marrow into circulation in response to injury or stress are aided by numerous chemokines and growth factors [55] that are known to be elevated within minutes to hours after IR $[4,56]$. Proinflammatory cytokines such as TNF- $\alpha$, IL- $1 \alpha$, and IL- 6 have been well documented to be regulated as a direct effect of gamma $(\gamma)$-IR in murine hematopoietic cells [57] and human epithelial cells [58]. However, high levels of proinflammatory cytokines after IR exposure can cause profound negative effects and perpetuate further DNA damage through induction of reactive oxygen and nitrogen species, which then may lead to the increased oxidative stress [59-61]. It has been shown that EPCs express lower levels of basal and stress-induced intracellular reactive oxygen species (ROS) than primary ECs because EPCs express higher levels of catalase, manganese superoxide dismutase (MnSOD), and glutathione peroxidase-1 (GPx-1) [62, 63]. Hence, inhibition of catalase, MnSOD, and GPx-1 [64] may increase ROS levels in EPCs, which in turn impairs EPC survival and migration [62]. As ischemic/damaged tissue is characterized by high levels of inflammatory cytokines which activate ROS production [65], it has been proposed that high levels of ROS metabolizing enzymes in EPCs are essential to maintain their survival during tissue regeneration after injury. Conversely, these findings suggest that an imbalance in ROS can contribute to EPC dysfunction and that oxidative stress may impair neovascularization, thereby contributing to the pathogenesis and the progression of $\mathrm{CV}$ disease risks.

Current understanding of low-dose space and terrestrial radiation and its biological effects is that direct damage of DNA in the nucleus causes cell death and mutations [12]. However, in the past two decades there have been numerous studies which suggest that radiation can cause damage in nonirradiated cells through radiobiological bystander responses (RBR) $[66,67]$. The term "bystander effect" was used to describe the ability of a cell, affected by radiation, to cause damage in other cells not directly traversed by the initial radiation [68]. It was suggested that generation of reactive oxygen and nitrogen species in IR tissues is mediated by increase in cytokines and chemokines [44, 6971] and this could be one of the main mechanisms for persistent nontargeted, RBR after IR [66, 67]. The role of the bystander responses in BM-derived EPC after ionizing 
particle radiation remains largely unknown. The main goal of this study was to determine whether space-type ${ }^{1} \mathrm{H}$ - and ${ }^{56} \mathrm{Fe}$-IR may induce RBR in BM-derived EPCs and evaluate the long term survival capacity of BM-EPCs after particle radiation.

We postulate that low-dose space IR-induced DNA damage responses in $\mathrm{BM}$ progenitor cell populations, including EPCs, may be of long duration and this may lead to significant decrease in the number of these cells, as well as long-term loss of EC function of BM-EPCs. This may then pose significant degenerative risk on physiologic homeostasis in the organs and tissue under conditions of normal aging and on repair and regeneration processes under pathologic conditions, such as injury or ischemia.

The acute phase of full-body low-dose IR induces apoptotic and immunological responses in the organ-tissues, including the heart [72], and is usually characterized by a neutrophil infiltration in affected area where macrophages are responsible for the phagocytic clearance of the apoptotic cells $[73,74]$. It has been shown that phagocytosis of IR-induced apoptotic cells can activate macrophages, which subsequently induce an inflammatory response in the surrounding tissue [75] by releasing various cytokines, superoxide, and nitric oxide [76]. This can provide a potential feedback loop mechanism perpetuating inflammatory response leading to endothelial cell dysfunction in the heart and stem and progenitor cell populations in the BM milieu, as well as in other organs and tissues. Our in vitro findings of significant increase in the levels of several cytokines and chemokines (known to induce radiobiological bystander responses) [11, 13] in ${ }^{1} \mathrm{H}$ - and ${ }^{56} \mathrm{Fe}-\mathrm{IR}$ BM-EPC conditioned media taken together with cyclical increase in BM-derived EPC apoptosis in in vivo studies may suggest a possible perpetuating mechanism of long-lasting IR-induced effects in the BM cell populations, including BM-EPCs. These findings in BMEPCs can be corroborated with IR-induced inflammatory changes in ECs resulting in modification of homeostasis and endothelial dysfunction [77].

NASA Human Research Program (HRP) identified space radiation as one of the space flight risk factors to the cardiovascular system which is vastly unknown and limited to information collected days to weeks after space missions [78]. In addition to the possible biological effects of exposure to ${ }^{1} \mathrm{H}$ and high charge and energy (HZE) ions (e.g., ${ }^{56} \mathrm{Fe}$ ), astronauts are also subjected to another critical physiological stressor, microgravity, which has been shown to produce untoward effects on the hematopoietic system and the BM microenvironment, leading to altered hematopoiesis-immunity [79-83] and cytokine production [84-87]. While most studies to-date examining DNA damage in the bone marrow environment as a result of exposure to IR have focused on direct effects on the stem and progenitor cell populations in BM milieu, recent studies $[88,89]$ have suggested that cytokines and signals within the BM tissue may play a key role in the ability of stem and progenitor cells to respond appropriately to IR-induced DNA damage. The effects of microgravity coupled with exposure to ionizing space radiation, both low-linear energy transfer (LET) proton $\left({ }^{1} \mathrm{H}\right)$ and high-LET iron $\left({ }^{56} \mathrm{Fe}\right)$, would eventually put astronauts in long-duration space missions at a higher risk of development of thrombotic diseases [90], manifestation of previously asymptomatic CV disease [78], immune dysfunction, and reduced vascular function and perfusion [91-94].

Epidemiologic data on IR-induced cardiovascular diseases from radiotherapy patients [95-97], nonoccupational exposure $[43,98,99]$, and occupational exposure has demonstrated that cardiovascular (CV) morbidity may occur within months or years, and CV mortality may occur within decades, after initial IR exposure. Since EPCs are embedded in the microenvironment of bone marrow stroma which is considered as the most concentrated reservoir [100] and are mobilized to the circulation in response to activation of several mobilizing signaling pathways [55, 101], ionizing radiation induced dysfunction in BM-EPCs can ultimately result in degenerative CV risks. Since the transition from proinflammatory to more anti-inflammatory environment is crucial for proper tissue recovery it is of the utmost importance that cell proliferation and resistance to radiation induced cell death in bystander cells is enhanced $[4,102]$.

\section{Summary}

It is important to substantiate here that studies using particle radiation such as proton and iron are not only important for future successful space exploration it is also vital for civilian population, as by 2012 more than 120,000 cancer patients in 16 counties [103] have been treated using particle radiation therapy, primarily protons but also including carbon and other HZE ions, with similar centers being planned and constructed every year. Therefore our studies may also provide a foundation for the development of therapeutic measures to prevent CV morbidity and mortality due to cancer radiotherapy (conventional and/or the particle), as well as accidental and occupational IR exposures.

\section{Conclusions}

The presence of persistent IR-induced DNA damage in BMEPCs along with increased apoptosis and possible impairment in DNA-repair characteristics of BM stem and progenitor cells may lead to BM-EPC dysfunction. This could then lead to the increase in $\mathrm{CV}$ degenerative risks in the form of cardiac fibrosis and eventually loss of cardiac function. We conclude that longitudinal studies using low-dose proton and heavy ion (HZE) radiation studies are warranted to determine IR-induced long-term CV risks.

\section{Conflict of Interests}

The authors declare no conflict of interests regarding the publication of this paper.

\section{Authors' Contributions}

Sharath P. Sasi performed and supervised all experimental studies, analyzed and interpreted data, and wrote and edited 
the paper; Daniel Park performed research, BM-EPC isolation, and culture and edited the paper; Sujatha Muralidharan performed research and edited the paper; Justin Wage performed research and both ex vivo and in vitro radiation studies; Albert Kiladjian performed research; Jillian Onufrak performed research; Heiko Enderling analyzed the data; Xinhua Yan analyzed data and edited the paper; David A. Goukassian conceived the study, designed research, analyzed and interpreted the data, and wrote and edited the paper.

\section{Acknowledgments}

This work was supported by the National Aeronautic and Space Administration (NASA) under Grant no. NNJ10ZSA001N and American Heart Association (AHA) Grant no. 14GRNT18860032 to David A. Goukassian. This work was also supported in part by Grants from AHA 10GRNT4710003 and NHLBI HL106098 to Xinhua Yan.

\section{References}

[1] G. E. Watson, D. A. Pocock, D. Papworth, S. A. Lorimore, and E. G. Wrights, "In vivo chromosomal instability and transmissible aberrations in the progeny of haemopoietic stem cells induced by high- and low-LET radiations," International Journal of Radiation Biology, vol. 77, no. 4, pp. 409-417, 2001.

[2] G. E. Watson, S. A. Lorimore, D. A. Macdonald, and E. G. Wright, "Chromosomal instability in unirradiated cells induced in vivo by a bystander effect of ionizing radiation," Cancer Research, vol. 60, no. 20, pp. 5608-5611, 2000.

[3] P. Todd, M. J. Pecaut, and M. Fleshner, "Combined effects of space flight factors and radiation on humans," Mutation Research, vol. 430, no. 2, pp. 211-219, 1999.

[4] D. Schaue, E. L. Kachikwu, and W. H. McBride, "Cytokines in radiobiological responses: a review," Radiation Research, vol. 178, no. 6, pp. 505-523, 2012.

[5] V. N. Ivanov, H. Zhou, S. A. Ghandhi et al., "Radiation-induced bystander signaling pathways in human fibroblasts: a role for interleukin-33 in the signal transmission," Cellular Signalling, vol. 22, no. 7, pp. 1076-1087, 2010.

[6] S. Hubackova, K. Krejcikova, J. Bartek, and Z. Hodny, "IL1and TGF $\beta$-Nox4 signaling, oxidative stress and DNA damage response are shared features of replicative, oncogene-induced, and drug-induced paracrine 'Bystander senescence," Aging, vol. 4, no. 12, pp. 932-951, 2012.

[7] W. F. Morgan, "Non-targeted and delayed effects of exposure to ionizing radiation: I. Radiation-induced genomic instability and bystander effects in vitro," Radiation Research, vol. 159, no. 5, pp. 567-580, 2003.

[8] K. D. Held, "Effects of low fluences of radiations found in space on cellular systems," International Journal of Radiation Biology, vol. 85, no. 5, pp. 379-390, 2009.

[9] I. Mosse, P. Marozik, C. Seymour, and C. Mothersill, "The effect of melanin on the bystander effect in human keratinocytes," Mutation Research, vol. 597, no. 1-2, pp. 133-137, 2006.

[10] M. Chinnadurai, S. Chidambaram, V. Ganesan et al., "Bleomycin, neocarzinostatin and ionising radiation-induced bystander effects in normal diploid human lung fibroblasts, bone marrow mesenchymal stem cells, lung adenocarcinoma cells and peripheral blood lymphocytes," International Journal of Radiation Biology, vol. 87, no. 7, pp. 673-682, 2011.
[11] T. K. Hei, H. Zhou, V. N. Ivanov et al., "Mechanism of radiationinduced bystander effects: a unifying model," The Journal of Pharmacy and Pharmacology, vol. 60, no. 8, pp. 943-950, 2008.

[12] S. A. Lorimore, P. J. Coates, and E. G. Wright, "Radiationinduced genomic instability and bystander effects: inter-related nontargeted effects of exposure to ionizing radiation," Oncogene, vol. 22, no. 45, pp. 7058-7069, 2003.

[13] S. P. Sasi, J. Song, D. Park et al., "TNF-TNFR2/p75 signaling inhibits early and increases delayed non-targeted effects in bone marrow-derived endothelial progenitor cells," The Journal of Biological Chemistry, vol. 289, no. 20, pp. 14178-14193, 2014.

[14] D. Orlic, J. Kajstura, S. Chimenti et al., "Bone marrow cells regenerate infarcted myocardium," Nature, vol. 410, no. 6829, pp. 701-705, 2001.

[15] C. Kalka, H. Masuda, T. Takahashi et al., "Transplantation of ex vivo expanded endothelial progenitor cells for therapeutic neovascularization," Proceedings of the National Academy of Sciences of the United States of America, vol. 97, no. 7, pp. 34223427,2000

[16] H. Kamihata, H. Matsubara, T. Nishiue et al., "Implantation of bone marrow mononuclear cells into ischemic myocardium enhances collateral perfusion and regional function via side supply of angioblasts, angiogenic ligands, and cytokines," Circulation, vol. 104, no. 9, pp. 1046-1052, 2001.

[17] T. Takahashi, C. Kalka, H. Masuda et al., "Ischemia- and cytokine-induced mobilization of bone marrow-derived endothelial progenitor cells for neovascularization," Nature Medicine, vol. 5, no. 4, pp. 434-438, 1999.

[18] U. Fischer-Rasokat, B. Assmus, F. H. Seeger et al., "A pilot trial to assess potential effects of selective Intracoronary bone marrow-derived progenitor cell infusion in patients with nonischemic dilated cardiomyopathy: final 1-year results of the transplantation of progenitor cells and functional regeneration enhancement pilot trial in patients with nonischemic dilated cardiomyopathy," Circulation: Heart Failure, vol. 2, no. 5, pp. 417-423, 2009.

[19] E. Tateishi-Yuyama, H. Matsubara, T. Murohara et al., “Therapeutic angiogenesis for patients with limb ischaemia by autologous transplantation of bone-marrow cells: a pilot study and a randomised controlled trial," The Lancet, vol. 360, no. 9331, pp. 427-435, 2002.

[20] V. Schächinger, B. Assmus, M. B. Britten et al., “Transplantation of progenitor cells and regeneration enhancement in acute myocardial infarction: final one-year results of the TOPCAREAMI trial," Journal of the American College of Cardiology, vol. 44, no. 8, pp. 1690-1699, 2004.

[21] J. van Ramshorst, J. J. Bax, S. L. M. A. Beeres et al., "Intramyocardial bone marrow cell injection for chronic myocardial ischemia: a randomized controlled trial," The Journal of the American Medical Association, vol. 301, no. 19, pp. 1997-2004, 2009.

[22] G. Qin, M. Ii, M. Silver et al., "Functional disruption of $\alpha 4$ integrin mobilizes bone marrow-derived endothelial progenitors and augments ischemic neovascularization," The Journal of Experimental Medicine, vol. 203, no. 1, pp. 153-163, 2006.

[23] R. Kishore, T. Tkebuchava, S. P. Sasi et al., "Tumor necrosis factor- $\alpha$ signaling via TNFR1/p55 is deleterious whereas TNFR2/p75 signaling is protective in adult infarct myocardium," Advances in Experimental Medicine and Biology, vol. 691, pp. 433-448, 2011.

[24] Y. Yao, Z. Sheng, Y. Li et al., "Tissue kallikrein promotes cardiac neovascularization by enhancing endothelial progenitor cell 
functional capacity," Human Gene Therapy, vol. 23, no. 8, pp. 859-870, 2012.

[25] C. Dubois, X. Liu, P. Claus et al., "Differential effects of progenitor cell populations on left ventricular remodeling and myocardial neovascularization after myocardial infarction," Journal of the American College of Cardiology, vol. 55, no. 20, pp. 2232-2243, 2010.

[26] P. Krishnamurthy, M. Thal, S. Verma et al., "Interleukin-10 deficiency impairs bone marrow-derived endothelial progenitor cell survival and function in ischemic myocardium," Circulation Research, vol. 109, no. 11, pp. 1280-1289, 2011.

[27] D. Goukassian, A. Díez-Juan, T. Asahara et al., "Overexpression of $\mathrm{p} 27^{\text {Kip } 1}$ by doxycycline-regulated adenoviral vectors inhibits endothelial cell proliferation and migration and impairs angiogenesis," The FASEB Journal, vol. 15, no. 11, pp. 1877-1885, 2001.

[28] D. A. Goukassian, G. Qin, C. Dolan et al., "Tumor necrosis factor- $\alpha$ receptor p75 is required in ischemia-induced neovascularization," Circulation, vol. 115, no. 6, pp. 752-762, 2007.

[29] S. P. Sasi, L. Rahimi, X. Yan et al., "Genetic deletion of TNFR2 augments inflammatory response and blunts satellitecell-mediated recovery response in a hind limb ischemia model," The FASEB Journal, 2014.

[30] D. Y. Lee, T.-J. Cho, J. A. Kim et al., "Mobilization of endothelial progenitor cells in fracture healing and distraction osteogenesis," Bone, vol. 42, no. 5, pp. 932-941, 2008.

[31] S. Sun, Z. Liu, H. Zhou et al., "The role of fucosylation in the promotion of endothelial progenitor cells in neovascularization and bone repair," Biomaterials, vol. 35, no. 12, pp. 3777-3785, 2014.

[32] Y. Shi, G. Kramer, A. Schröder et al., "Early endothelial progenitor cells as a source of myeloid cells to improve the prevascularisation of bone constructs," European Cells \& Materials, vol. 27, pp. 64-80, 2014.

[33] H. Zigdon-Giladi, T. Bick, D. Lewinson, and E. E. Machtei, "Co-Transplantation of endothelial progenitor cells and mesenchymal stem cells promote neovascularization and bone regeneration," Clinical Implant Dentistry and Related Research, 2013.

[34] S. Cherqui, S. M. Kurian, O. Schussler, J. A. Hewel, J. R. Yates III, and D. R. Salomon, "Isolation and angiogenesis by endothelial progenitors in the fetal liver," Stem Cells, vol. 24, no. 1, pp. 44-54, 2006.

[35] J. Lian, Y. Lu, P. Xu et al., "Prevention of liver fibrosis by intrasplenic injection of high-density cultured bone marrow cells in a rat chronic liver injury model," PLoS ONE, vol. 9, no. 9, Article ID e103603, 2014.

[36] S. Kaur, D. Tripathi, K. Dongre et al., "Increased number and function of endothelial progenitor cells stimulate angiogenesis by resident liver sinusoidal endothelial cells (SECs) in cirrhosis through paracrine factors," Journal of Hepatology, vol. 57, no. 6, pp. 1193-1198, 2012.

[37] N. Hecht, U. C. Schneider, M. Czabanka et al., "Endothelial progenitor cells augment collateralization and hemodynamic rescue in a model of chronic cerebral ischemia," Journal of Cerebral Blood Flow and Metabolism, vol. 34, pp. 1297-1305, 2014.

[38] L. Pellegrini, Y. Bennis, B. Guillet et al., "Therapeutic benefit of a combined strategy using erythropoietin and endothelial progenitor cells after transient focal cerebral ischemia in rats," Neurological Research, vol. 35, no. 9, pp. 937-947, 2013.

[39] N. Kamei, S.-M. Kwon, C. Alev et al., "Ex-vivo expanded human blood-derived $\mathrm{CD}_{133^{+}}$cells promote repair of injured spinal cord," Journal of the Neurological Sciences, vol. 328, no. 1-2, pp. 41-50, 2013.

[40] A. Rosell, A. Morancho, M. Navarro-Sobrino et al., "Factors secreted by endothelial progenitor cells enhance neurorepair responses after cerebral ischemia in mice," PLOS ONE, vol. 8, no. 9, Article ID e73244, 2013.

[41] Y. Fan, F. Shen, T. Frenzel et al., "Endothelial progenitor cell transplantation improves long-term stroke outcome in mice," Annals of Neurology, vol. 67, no. 4, pp. 488-497, 2010.

[42] T. Asahara, T. Takahashi, H. Masuda et al., "VEGF contributes to postnatal neovascularization by mobilizing bone marrowderived endothelial progenitor cells," The EMBO Journal, vol. 18, no. 14, pp. 3964-3972, 1999.

[43] I. Emerit, A. Levy, L. Cernjavski et al., “Transferable clastogenic activity in plasma from persons exposed as salvage personnel of the Chernobyl reactor," Journal of Cancer Research and Clinical Oncology, vol. 120, no. 9, pp. 558-561, 1994.

[44] C. Bubici, S. Papa, K. Dean, and G. Franzoso, "Mutual crosstalk between reactive oxygen species and nuclear factor-kappa B: molecular basis and biological significance," Oncogene, vol. 25, no. 51, pp. 6731-6748, 2006.

[45] S. A. Amundson, M. B. Grace, C. B. McLeland et al., "Human in vivo radiation-induced biomarkers: gene expression changes in radiotherapy patients," Cancer Research, vol. 64, no. 18, pp. 6368-6371, 2004.

[46] M. B. Grace and W. F. Blakely, "Transcription of five p53and Stat-3-inducible genes after ionizing radiation," Radiation Measurements, vol. 42, no. 6-7, pp. 1147-1151, 2007.

[47] D. Trivigno, L. Bornes, S. M. Huber, and J. Rudner, "Regulation of protein translation initiation in response to ionizing radiation," Radiation Oncology, vol. 8, no. 1, article 35, 2013.

[48] M. Chen, J. Quintans, Z. Fuks, C. Thompson, D. W. Kufe, and R. R. Weichselbaum, "Suppression of Bcl-2 messenger RNA production may mediate apoptosis after ionizing radiation, tumor necrosis factor alpha, and ceramide," Cancer Research, vol. 55, no. 5, pp. 991-994, 1995.

[49] T. Kanzawa, E. Iwado, H. Aoki et al., "Ionizing radiation induces apoptosis and inhibits neuronal differentiation in rat neural stem cells via the c-Jun $\mathrm{NH}_{2}$-terminal kinase (JNK) pathway," Oncogene, vol. 25, no. 26, pp. 3638-3648, 2006.

[50] T. Asahara, T. Murohara, A. Sullivan et al., "Isolation of putative progenitor endothelial cells for angiogenesis," Science (New York, N.Y.), vol. 275, no. 5302, pp. 964-967, 1997.

[51] M. Vasa, S. Fichtlscherer, K. Adler et al., "Increase in circulating endothelial progenitor cells by statin therapy in patients with stable coronary artery disease," Circulation, vol. 103, no. 24, pp. 2885-2890, 2001.

[52] O. M. Tepper, R. D. Galiano, J. M. Capla et al., "Human endothelial progenitor cells from type II diabetics exhibit impaired proliferation, adhesion, and incorporation into vascular structures," Circulation, vol. 106, no. 22, pp. 2781-2786, 2002.

[53] J. M. Hill, G. Zalos, J. P. J. Halcox et al., "Circulating endothelial progenitor cells, vascular function, and cardiovascular risk," The New England Journal of Medicine, vol. 348, no. 7, pp. 593-600, 2003.

[54] C. J. M. Loomans, E. J. P. De Koning, F. J. T. Staal et al., "Endothelial progenitor cell dysfunction: a novel concept in the pathogenesis of vascular complications of type 1 diabetes," Diabetes, vol. 53, no. 1, pp. 195-199, 2004. 
[55] S. Ray, S. S. Kulkarni, K. Chakraborty et al., "Mobilization of progenitor cells into peripheral blood by gammatocotrienol: a promising radiation countermeasure," International Immunopharmacology, vol. 15, no. 3, pp. 557-564, 2013.

[56] C. Petit-Frère, E. Capulas, D. A. Lyon et al., "Apoptosis and cytokine release induced by ionizing or ultraviolet $\mathrm{B}$ radiation in primary and immortalized human keratinocytes," Carcinogenesis, vol. 21, no. 6, pp. 1087-1095, 2000.

[57] C.-M. Chang, A. Limanni, W. H. Baker, M. E. Dobson, J. F. Kalinich, and M. L. Patchen, "Sublethal gamma irradiation increases IL-1 $\alpha$, IL-6, and TNF- $\alpha$ mRNA levels in murine hematopoietic tissues," Journal of Interferon \& Cytokine Research, vol. 17, no. 9, pp. 567-572, 1997.

[58] A. Beetz, G. Messer, T. Oppel, D. van Beuningen, R. U. Peter, and P. Kind, "Induction of interleukin 6 by ionizing radiation in a human epithelial cell line: control by corticosteroids," International Journal of Radiation Biology, vol. 72, no. 1, pp. 3343, 1997.

[59] D. R. Spitz, E. I. Azzam, J. J. Li, and D. Gius, "Metabolic oxidation/reduction reactions and cellular responses to ionizing radiation: a unifying concept in stress response biology," Cancer and Metastasis Reviews, vol. 23, no. 3-4, pp. 311-322, 2004.

[60] W. F. Morgan, "Communicating non-targeted effects of ionizing radiation to achieve adaptive homeostasis in tissues," Current Molecular Pharmacology, vol. 4, no. 2, pp. 135-140, 2011.

[61] E. I. Azzam, J.-P. Jay-Gerin, and D. Pain, "Ionizing radiationinduced metabolic oxidative stress and prolonged cell injury," Cancer Letters, vol. 327, no. 1-2, pp. 48-60, 2012.

[62] E. Dernbach, C. Urbich, R. P. Brandes, W. K. Hofmann, A. M. Zeiher, and S. Dimmeler, "Antioxidative stress-associated genes in circulating progenitor cells: evidence for enhanced resistance against oxidative stress," Blood, vol. 104, no. 12, pp. 3591-3597, 2004.

[63] T. He, T. E. Peterson, E. L. Holmuhamedov et al., "Human endothelial progenitor cells tolerate oxidative stress due to intrinsically high expression of manganese superoxide dismutase," Arteriosclerosis, Thrombosis, and Vascular Biology, vol. 24, no. 11, pp. 2021-2027, 2004.

[64] M. Raes, C. Michiels, and J. Remacle, "Comparative study of the enzymatic defense systems against oxygen-derived free radicals: the key role of glutathione peroxidase," Free Radical Biology \& Medicine, vol. 3, no. 1, pp. 3-7, 1987.

[65] T. Cramer, Y. Yamanishi, B. E. Clausen et al., "HIF-1 $\alpha$ is essential for myeloid cell-mediated inflammation," Cell, vol. 112, no. 5, pp. 645-657, 2003.

[66] C. Mothersill, R. J. Seymour, and C. B. Seymour, "Increased radiosensitivity in cells of two human cell lines treated with bystander medium from irradiated repair-deficient cells," Radiation Research, vol. 165, no. 1, pp. 26-34, 2006.

[67] D. Averbeck, "Non-targeted effects as a paradigm breaking evidence," Mutation Research/Fundamental and Molecular Mechanisms of Mutagenesis, vol. 687, no. 1-2, pp. 7-12, 2010.

[68] B. Djordjevic, "Bystander effects: a concept in need of clarification," BioEssays, vol. 22, no. 3, pp. 286-290, 2000.

[69] M. Boerma and M. Hauer-Jensen, "Preclinical research into basic mechanisms of radiation-induced heart disease," Cardiology Research and Practice, vol. 1, no. 1, Article ID 858262, 2011.

[70] T.-K. Lee, K. F. O’brien, W. Wang et al., "Radioprotective effect of american ginseng on human lymphocytes at 90 minutes postirradiation: a study of 40 cases," Journal of Alternative and Complementary Medicine, vol. 16, no. 5, pp. 561-567, 2010.
[71] K. G. Soucy, H. K. Lim, D. O. Attarzadeh et al., "Dietary inhibition of xanthine oxidase attenuates radiation-induced endothelial dysfunction in rat aorta," Journal of Applied Physiology, vol. 108, no. 5, pp. 1250-1258, 2010.

[72] R. Pandey, B. S. Shankar, D. Sharma, and K. B. Sainis, "Low dose radiation induced immunomodulation: effect on macrophages and $\mathrm{CD}^{+} \mathrm{T}$ cells," International Journal of Radiation Biology, vol. 81, no. 11, pp. 801-812, 2005.

[73] E. G. Wright and P. J. Coates, "Untargeted effects of ionizing radiation: implications for radiation pathology," Mutation Research, vol. 597, no. 1-2, pp. 119-132, 2006.

[74] S. A. Lorimore, P. J. Coates, G. E. Scobie, G. Milne, and E. G. Wright, "Inflammatory-type responses after exposure to ionizing radiation in vivo: a mechanism for radiation-induced bystander effects?" Oncogene, vol. 20, no. 48, pp. 7085-7095, 2001.

[75] I. N. Mungrue, R. Gros, X. You et al., "Cardiomyocyte overexpression of iNOS in mice results in peroxynitrite generation, heart block, and sudden death," The Journal of Clinical Investigation, vol. 109, no. 6, pp. 735-743, 2002.

[76] G. Kojda, J. B. Laursen, S. Ramasamy et al., "Protein expression, vascular reactivity and soluble guanylate cyclase activity in mice lacking the endothelial cell nitric oxide synthase: contributions of NOS isoforms to blood pressure and heart rate control," Cardiovascular Research, vol. 42, no. 1, pp. 206-213, 1999.

[77] J. Wang, H. Zheng, X. Ou, L. M. Fink, and M. HauerJensen, "Deficiency of microvascular thrombomodulin and upregulation of protease-activated receptor-1 in irradiated rat intestine: possible link between endothelial dysfunction and chronic radiation fibrosis," The American Journal of Pathology, vol. 160, no. 6, pp. 2063-2072, 2002.

[78] V. A. Convertino, "Status of cardiovascular issues related to space flight: implications for future research directions," Respiratory Physiology \& Neurobiology, vol. 169, supplement, pp. S34S37, 2009.

[79] J. W. Armstrong, R. A. Gerren, and S. K. Chapes, “The effect of space and parabolic flight on macrophage hematopoiesis and function," Experimental Cell Research, vol. 216, no. 1, pp. 160168, 1995.

[80] A. Cogoli, A. Tschopp, and P. Fuchs-Bislin, "Cell sensitivity to gravity," Science (New York, N.Y.), vol. 225, no. 4658, pp. 228230, 1984.

[81] V. N. Shvets and V. V. Portugalov, "Space flight effects on the hemopoietic function of bone marrow of the rat," Aviation Space and Environmental Medicine, vol. 47, no. 7, pp. 746-749, 1976.

[82] I. Walther, A. Cogoli, P. Pippia et al., "Human immune cells as space travelers," European journal of medical research, vol. 4, no. 9, pp. 361-363, 1999.

[83] I. Walther, P. Pippia, M. A. Meloni, F. Turrini, F. Mannu, and A. Cogoli, "Simulated microgravity inhibits the genetic expression of interleukin-2 and its receptor in mitogen-activated T lymphocytes," FEBS Letters, vol. 436, no. 1, pp. 115-118, 1998.

[84] S. K. Chapes, S. J. Simske, A. D. Forsman, T. A. Bateman, and R. J. Zimmerman, "Effects of space flight and IGF-1 on immune function," Advances in Space Research, vol. 23, no. 12, pp. 1955$1964,1999$.

[85] B. E. Crucian, M. L. Cubbage, and C. F. Sams, "Altered cytokine production by specific human peripheral blood cell subsets immediately following space flight," Journal of Interferon \& Cytokine Research, vol. 20, no. 6, pp. 547-556, 2000. 
[86] D. Meshkov and M. Rykova, "The natural cytotoxicity in cosmonauts on board space stations," Acta Astronautica, vol. 36, no. 8-12, pp. 719-726, 1995.

[87] G. Sonnenfeld, "Effect of space flight on cytokine production," Acta Astronautica, vol. 33, pp. 143-147, 1994.

[88] B. de Laval, P. Pawlikowska, L. Petit-Cocault et al., "Thrombopoietin-increased DNA-PK-dependent DNA repair limits hematopoietic stem and progenitor cell mutagenesis in response to dna damage," Cell Stem Cell, vol. 12, no. 1, pp. 3748, 2013.

[89] C. L. Carbonneau, G. Despars, S. Rojas-Sutterlin et al., "Ionizing radiation-induced expression of INK4a/ARF in murine bone marrow-derived stromal cell populations interferes with bone marrow homeostasis," Blood, vol. 119, no. 3, pp. 717-726, 2012.

[90] A. L. Romero-Weaver, L. Lin, A. Carabe-Fernandez, and A. R. Kennedy, "Effects of solar particle event-like proton radiation and/or simulated microgravity on circulating mouse blood cells," Gravitational and Space Research, vol. 2, pp. 42-53, 2014.

[91] P. N. Colleran, B. J. Behnke, M. K. Wilkerson, A. J. Donato, and M. D. Delp, "Simulated microgravity alters rat mesenteric artery vasoconstrictor dynamics through an intracellular $\mathrm{Ca}^{2+}$ release mechanism," American Journal of Physiology-Regulatory, Integrative and Comparative Physiology, vol. 294, no. 5, pp. R1577R1585, 2008.

[92] P. N. Colleran, M. K. Wilkerson, S. A. Bloomfield, L. J. Suva, R. T. Turner, and M. D. Delp, "Alterations in skeletal perfusion with simulated microgravity: a possible mechanism for bone remodeling," Journal of Applied Physiology, vol. 89, no. 3, pp. 1046-1054, 2000.

[93] J. Powers and D. Bernstein, "The mouse as a model of cardiovascular adaptations to microgravity," Journal of Applied Physiology, vol. 97, no. 5, pp. 1686-1692, 2004.

[94] S. K. Chapes, A. M. Mastro, G. Sonnenfeld, and W. D. Berry, "Antiorthostatic suspension as a model for the effects of spaceflight on the immune system," Journal of Leukocyte Biology, vol. 54, no. 3, pp. 227-235, 1993.

[95] G. Gyenes, T. Fornander, P. Carlens, and L. E. Rutqvist, "Morbidity of ischemic heart disease in early breast cancer 1520 years after adjuvant radiotherapy," International Journal of Radiation Oncology Biology Physics, vol. 28, no. 5, pp. 1235-1241, 1994.

[96] C. W. Taylor, P. McGale, and S. C. Darby, "Cardiac risks of breast-cancer radiotherapy: a contemporary view," Clinical Oncology, vol. 18, no. 3, pp. 236-246, 2006.

[97] I. W. Gayed, H. H. Liu, S. W. Yusuf et al., "The prevalence of myocardial ischemia after concurrent chemoradiation therapy as detected by gated myocardial perfusion imaging in patients with esophageal cancer," Journal of Nuclear Medicine, vol. 47, no. 11, pp. 1756-1762, 2006.

[98] A. S. C. Bose, V. Shetty, A. Sadiq, J. Shani, and I. Jacobowitz, "Radiation induced cardiac valve disease in a man from Chernobyl," Journal of the American Society of Echocardiography, vol. 22, no. 8, pp. 973.el-973.e3, 2009.

[99] G. Shankar Pant and N. Kamada, "Chromosome aberrations in normal leukocytes induced by the plasma of exposed individuals," Hiroshima Journal of Medical Sciences, vol. 26, no. 2-3, pp. 149-154, 1977.

[100] S. C. Pitchford, R. C. Furze, C. P. Jones, A. M. Wengner, and S. M. Rankin, "Differential mobilization of subsets of progenitor cells from the bone marrow," Cell Stem Cell, vol. 4, no. 1, pp. 6272, 2009.
[101] F. Fleissner and T. Thum, "The IGF-1 receptor as a therapeutic target to improve endothelial progenitor cell function," Molecular Medicine, vol. 14, no. 5-6, pp. 235-237, 2008.

[102] H. P. Rodemann and M. A. Blaese, "Responses of normal cells to ionizing radiation," Seminars in Radiation Oncology, vol. 17, no. 2, pp. 81-88, 2007.

[103] M. Jermann, "Particle therapy statistics in 2013," International Journal of Particle Therapy, vol. 1, no. 1, pp. 40-43, 2014. 

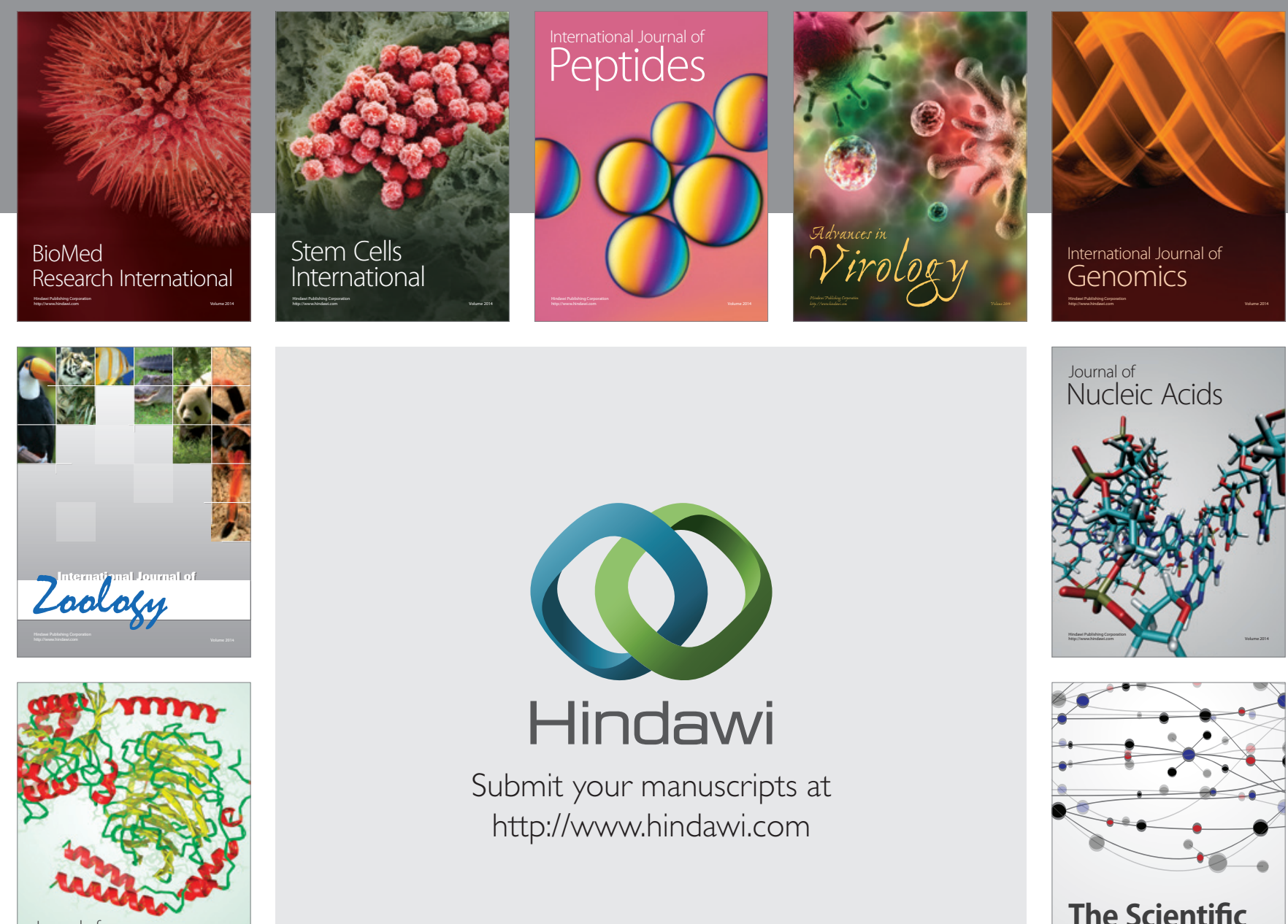

Submit your manuscripts at

http://www.hindawi.com

Journal of
Signal Transduction
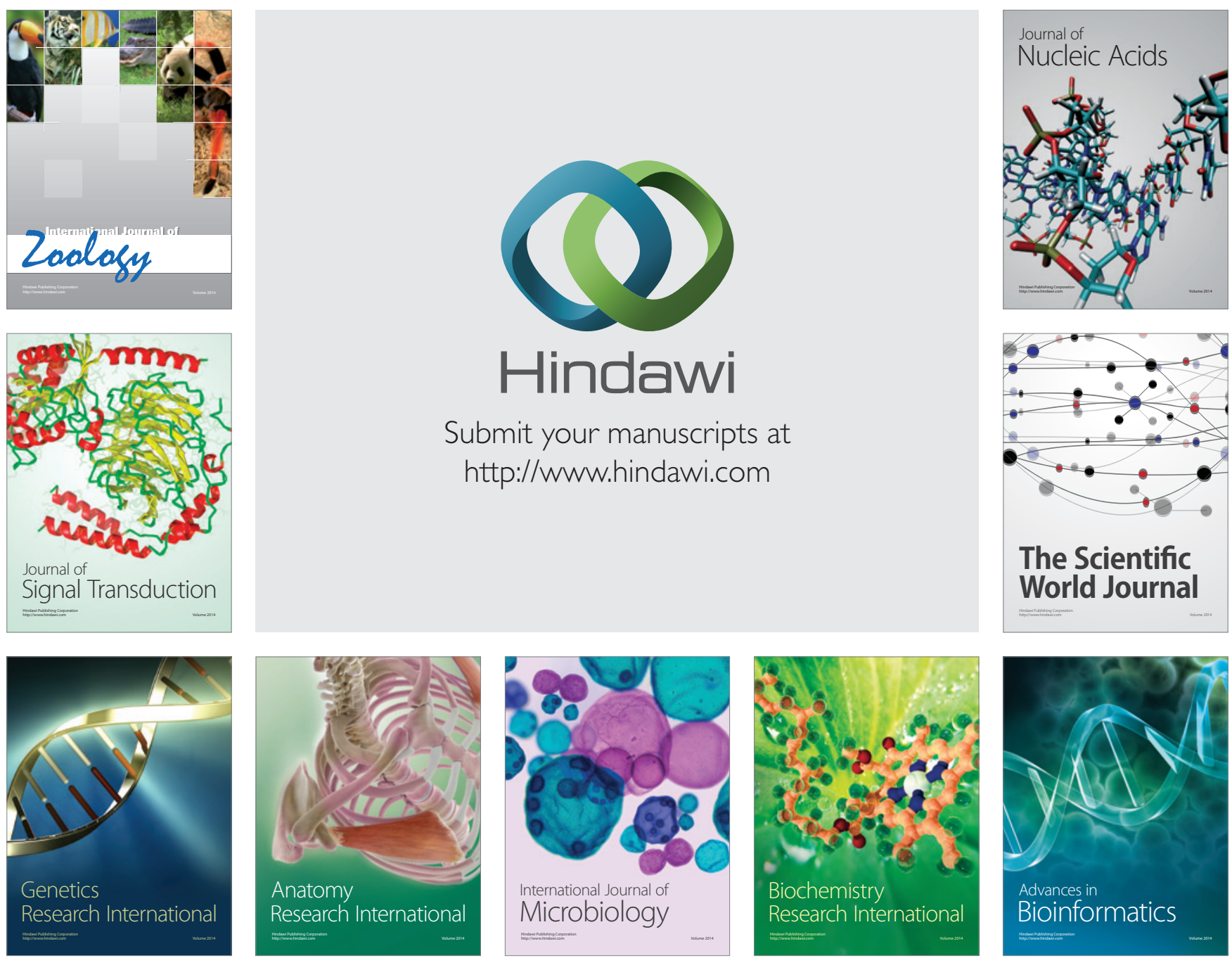

The Scientific World Journal
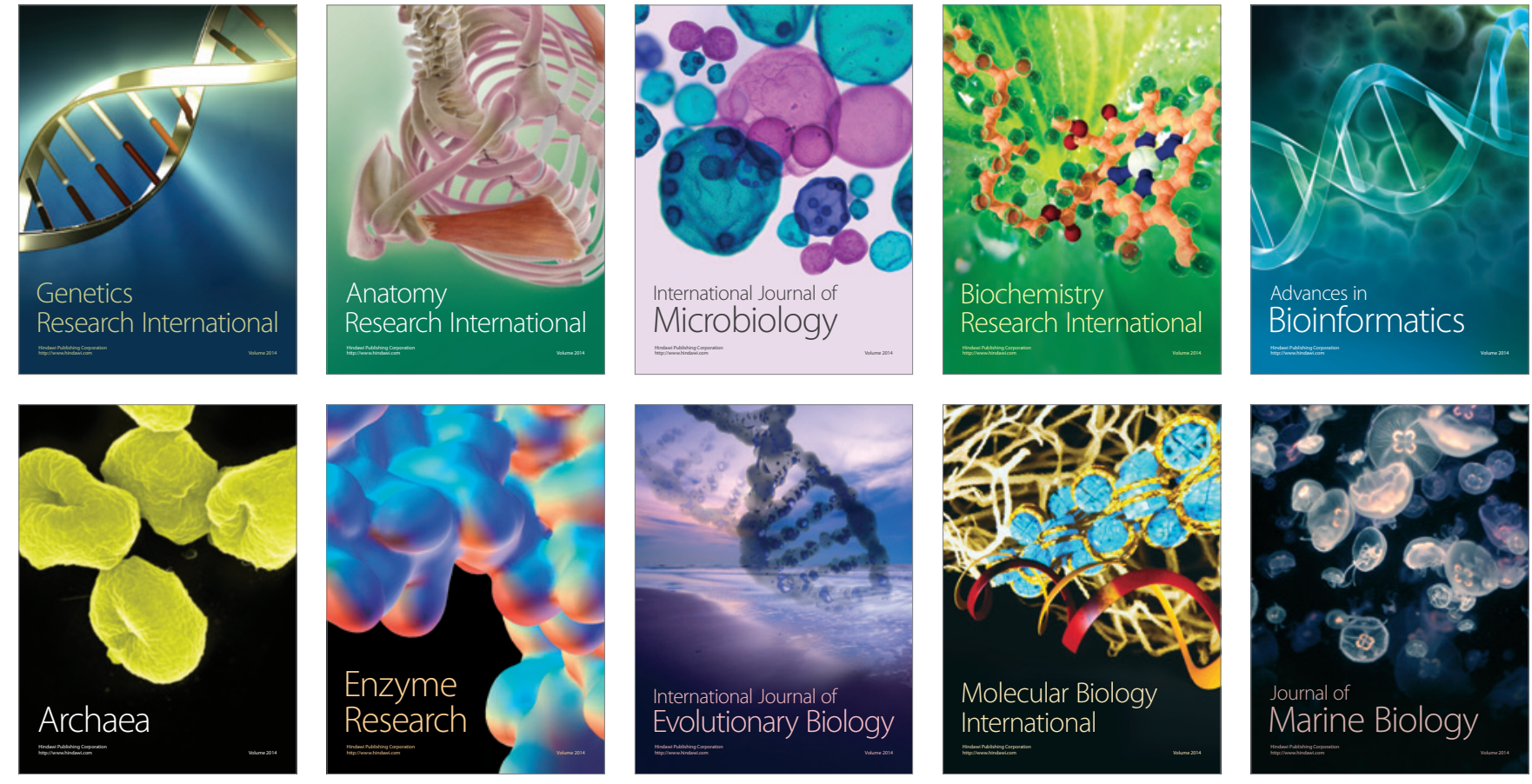